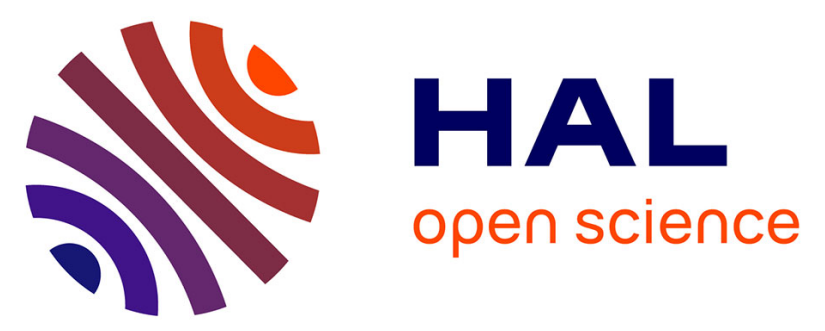

\title{
Removal of methylene blue from aqueous solutions using a solid residue of the apple juice industry: full factorial design, equilibrium, thermodynamics and kinetics aspects \\ L.R. Bonetto, J.S. Crespo, Régis Guégan, V.I. Esteves, M. Giovanela
}

\section{To cite this version:}

L.R. Bonetto, J.S. Crespo, Régis Guégan, V.I. Esteves, M. Giovanela. Removal of methylene blue from aqueous solutions using a solid residue of the apple juice industry: full factorial design, equilibrium, thermodynamics and kinetics aspects. Journal of Molecular Structure, 2021, 1224, pp.129296. 10.1016/j.molstruc.2020.129296 . insu-02945176

\section{HAL Id: insu-02945176 \\ https://hal-insu.archives-ouvertes.fr/insu-02945176}

Submitted on 22 Sep 2020

HAL is a multi-disciplinary open access archive for the deposit and dissemination of scientific research documents, whether they are published or not. The documents may come from teaching and research institutions in France or abroad, or from public or private research centers.
L'archive ouverte pluridisciplinaire HAL, est destinée au dépôt et à la diffusion de documents scientifiques de niveau recherche, publiés ou non, émanant des établissements d'enseignement et de recherche français ou étrangers, des laboratoires publics ou privés. 


\section{Journal Pre-proof}

Removal of methylene blue from aqueous solutions using a solid residue of the apple juice industry: full factorial design, equilibrium, thermodynamics and kinetics aspects

L.R. Bonetto, J.S. Crespo, R. Guégan, V.I. Esteves , M. Giovanela

PII:

DOI:

Reference:

To appear in:

Received date:

Revised date:

Accepted date:
S0022-2860(20)31616-1

https://doi.org/10.1016/j.molstruc.2020.129296

MOLSTR 129296
Journal of

\section{MOLECULAR \\ STRUGTURE}

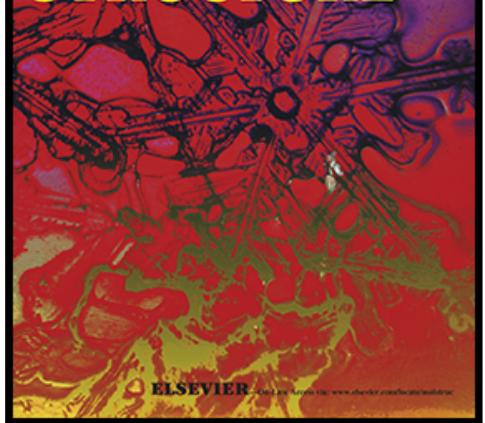

Please cite this article as: L.R. Bonetto, J.S. Crespo, R. Guégan, V.I. Esteves, M. Giovanela , Removal of methylene blue from aqueous solutions using a solid residue of the apple juice industry: full factorial design, equilibrium, thermodynamics and kinetics aspects, Journal of Molecular Structure (2020), doi: https://doi.org/10.1016/j.molstruc.2020.129296

This is a PDF file of an article that has undergone enhancements after acceptance, such as the addition of a cover page and metadata, and formatting for readability, but it is not yet the definitive version of record. This version will undergo additional copyediting, typesetting and review before it is published in its final form, but we are providing this version to give early visibility of the article. Please note that, during the production process, errors may be discovered which could affect the content, and all legal disclaimers that apply to the journal pertain.

(C) 2020 Published by Elsevier B.V. 


\section{HIGHLIGHTS}

- A solid agro-industrial residue was used for removal of methylene blue by adsorption.

- Significant second-order interactions were found for the response variables.

- A Langmuir model provided the best fit for equilibrium isotherm data.

- Kinetic studies showed that external and internal diffusion can control adsorption.

- Adsorbent can be recycled up to five times without significant loss of properties. 


\title{
Removal of methylene blue from aqueous solutions using a solid
}

\author{
residue of the apple juice industry: full factorial design,
} equilibrium, thermodynamics and kinetics aspects

L. R. Bonetto ${ }^{\mathrm{a}, *}$, J. S. Crespo ${ }^{\mathrm{a}}$, R. Guégan ${ }^{\mathrm{b}, \mathrm{c}}$, V. I. Esteves ${ }^{\mathrm{d}}$, M. Giovanela ${ }^{\mathrm{a}, *}$

${ }^{a}$ Área do Conhecimento de Ciências Exatas e Engenharias, Universidade de Caxias do Sul, 95070-560 Caxias do Sul-RS, Brazil.

${ }^{b}$ Institut des Sciences de la Terre d'Orléans, UMR 7327, CNRS-Université d'Orléans, 1 A Rue de la Férollerie, 45071 Orléans Cedex 2, France

${ }^{c}$ Faculty of Science and Engineering, Global Center for Science and Engineering, Waseda University, 3-4-1 Okubo, Shinjuku-ku, Tokyo, 169-8555, Japan

${ }^{d}$ Department of Chemistry and Centre for Environmental and Marine Studies (CESAM), University of Aveiro, Campus de Santiago, 3810-193 Aveiro, Portugal

Corresponding authors: M. Giovanela and L. R. Bonetto.

E-mail: mgiovan1@ucs.br and lrbonett@ucs.br 


\section{ABSTRACT}

The use of adsorbent materials derived from agro-industrial residues represents a simple, easy and low-cost process for the removal of dyes from aqueous solutions. In this context, this study aimed to evaluate the use of a solid residue from the apple juice industry in the removal of methylene blue (MB) dye. Several different analytical techniques, including elemental analysis, Fourier transform infrared spectroscopy, solid-state ${ }^{13} \mathrm{C}$ nuclear magnetic resonance, nitrogen adsorption/desorption and determination of $\mathrm{pH}$ at zero-point charge, were used to investigate the physico-chemical properties of the apple pomace. Conventional bath experiments were carried out by simultaneously optimizing five variables (initial MB concentration, amount of adsorbent, $\mathrm{pH}$, stirring frequency and temperature) using a full $2^{k}$ factorial design with central point. In general, the characterization analyses evidenced the presence of several types of oxygenated functional groups in the adsorbent chemical structure and a favorable morphology for dye removal. Furthermore, the initial MB concentration, the amount of adsorbent and the $\mathrm{pH}$ of the medium had the strongest effect on the response variables, including their interactions and quadratic terms. In terms of equilibrium, it was found that the Langmuir model gave a good fit to the data, while the thermodynamic parameters indicated that the process was spontaneous and exothermic in nature. Moreover, kinetic studies revealed that the MB removal rate followed a pseudo-second-order model, suggesting an adsorption controlled by either diffusion on the stagnant film covering the adsorbent particles or intraparticle diffusion. Finally, the data acquired in this study also emphasized the interest to use materials derived from agro-industrial residues as potential adsorbents in the light of its properties for the removal of basic dyes, including MB.

Keywords: apple pomace; methylene blue; removal; equilibrium; thermodynamics; kinetics 


\section{INTRODUCTION}

Water is an essential natural resource for life and for the sustainable development of the economy. Over recent decades, climate change and socioeconomic development have significantly affected the hydrological cycle, compromising not only the quality of the water available for human consumption, but also the health and biodiversity of aquatic environments. Thus, considerable attention has been paid to the preservation and recovery of water sources, and to issues related to the problem of water scarcity [1].

Among the problems related to industrial activities are the generation and improper disposal of waste. A total of $20 \%$ of all global pollution is caused by textile companies [2]. This type of industry uses large facilities for production operations, and generates a huge amount of wastewater as a consequence of various finishing processes such as sizing, washing, bleaching, mercerizing, dyeing and stamping [3]. Of the total amount of dyes commonly used by textile companies, about $12 \%$ (almost 700,000 tons) is lost at various stages of the manufacturing and processing operations [4].

Currently, methylene blue (MB) dye is one of the most commonly used substances for coloring cotton, wood and silk [5]. This dye is very resistant to biodegradation, due to the presence of aromatic rings with high chemical stability [6,7]. With regard to toxicity, direct and excessive contact with MB can cause several detrimental effects to the health of animals and humans, including diseases such as hemolytic anemia, nausea, vomiting, abdominal and chest pain, high fever, hemolysis and cyanosis, in concentrations above $2.0 \mathrm{mg} \mathrm{kg}^{-1}$ [8]. The presence of MB in sources of water for community supply must therefore be strictly avoided.

With the aim of removing and reducing the environmental impacts caused by dyes, several methods for the treatment of dye-containing wastewater have been developed and are currently being investigated and improved, such as advanced oxidative processes, 
coagulation, electrochemical, biodegradation and adsorption [9]. The latter approach, in particular, is notable for using adsorbents from agro-industrial residues, including fruit pomaces [10], pine nut peel [11], sugarcane [12], orange [13] and citrus limetta peels [14], among others, and thus shows promise as an economic and environmentally friendly technique.

Most of these materials have high adsorptive potential for various classes of pollutants due to their composition, which includes cellulose, hemicellulose and lignin, as well as lipids, proteins, enzymes and hydrocarbons. In addition, they generally do not require pretreatment, and this also reduces the preparation costs, which are much lower than those associated with heat treatments in the production of activated carbon [15].

The use of agro-industrial wastes generated within a given region has a number of benefits. In this work, we chose to use apple residues from the juice and derivatives industry, which are produced in large quantities within the Rio Grande do Sul State (RS, southern Brazil). According to data from the Brazilian Apple Growers Association (2019) [16], RS is the second largest national apple producer. Of the total production of apples, which exceeded 490,000 tons in the $2017 / 2018$ harvest, about $20 \%$ to $25 \%$ is used in the production of juices, and $20 \%$ to $40 \%$ of this quantity becomes pomace [17].

Apple pomace mainly comprises peel and pulp (94.5\%), seeds (4.4\%) and centers (1.1\%) [18], and contains on average $80 \%$ moisture, $6 \%$ fiber and $14 \%$ solids, consisting of a mixture of glucose, fructose and sucrose [7]. The structures of these compounds have several oxygenated functional groups, which can interact with dyes, metals, and proteins, among other substances [19]. In general, the presence of sugars in the composition of the apple pomace makes it very susceptible to spoilage by microorganisms and therefore the improper disposal of this solid residue in the environment can result in a number of damages, such as a reduction of soil productivity and/or decrease in the concentration of dissolved oxygen in 
water bodies that receive slurry from the decomposition of this waste [20]. Thus, its reuse as an adsorbent is beneficial from both perspectives and can be a way to help manage solid wastes from juice industries [4].

In view of all these facts, the main objectives of the present work were to evaluate the morphological and physico-chemical properties of a solid waste (pomace) from the apple juice industry and to investigate the equilibrium, thermodynamics and kinetics of the adsorption process of MB dye using this agro-industrial residue. Furthermore, full factorial (interacted variables) design, as a powerful tool for optimization was applied to determine and verify the optimum conditions that maximize the MB removal efficiency.

\section{EXPERIMENTAL}

\subsection{Materials, reagents and glassware cleaning procedure}

A sample of apple pomace (Gala cultivar) was purchased from Sumabrás do Brasil Indústria e Comércio de Sucos de Maçã Ltda (Vacaria, RS, Brazil) and stored in an ultrafreezer at $-20^{\circ} \mathrm{C}$. Before analysis, the material was thawed at room temperature, dried at 50 ${ }^{\circ} \mathrm{C}$ at a forced circulation oven and crushed using a knife mill. At the end of this procedure, the sample was kept in polypropylene bottles in a desiccator, and was used without any physical or chemical pretreatment.

MB (Fig. 1) $\left(\mathrm{C}_{16} \mathrm{H}_{18} \mathrm{ClN}_{3} \mathrm{~S} .3 \mathrm{H}_{2} \mathrm{O}\right.$, color index 52015) was acquired from Vetec Química Fina Ltda (Rio de Janeiro, RJ, Brazil). The chemicals used in this work $\left(\mathrm{KNO}_{3}\right.$, $\mathrm{KOH}, \mathrm{HNO}_{3}, \mathrm{HCl}, \mathrm{NaOH}$ and ethanol - Merck, São Paulo, SP, Brazil) were of analytical 
grade. All aqueous solutions were prepared using deionized water (18.2 $\mathrm{M} \Omega \mathrm{cm}$ resistivity) obtained from a Millipore Milli-Q UV Direct-Q 3 UV system (Darmstadt, Germany).

\subsection{Characterization of the adsorbent}

The relative quantities of $\mathrm{C}, \mathrm{H}, \mathrm{N}$ and $\mathrm{S}$ in the apple pomace sample were measured directly with a Truspec 630-200-200 elemental analyzer (Mönchenladbach, Germany). The proportion of oxygen was estimated as the difference between the total concentrations of carbon, hydrogen, nitrogen and sulfur and $100 \%$. The identification of the main functional groups was performed using Fourier transform infrared (FT-IR) spectroscopy. The spectrum was recorded on a Thermo Scientific NICOLET iS10 spectrophotometer (Waltham, MA, United States of America) with a nominal resolution of $4.0 \mathrm{~cm}^{-1}$ and within a spectral range of $4,000-400 \mathrm{~cm}^{-1}$.

A semi-quantification of the different types of carbon in the structure of the apple pomace sample was performed by integrating the resonance peaks present in the solid-state

${ }^{13} \mathrm{C}$ nuclear magnetic resonance $\left({ }^{13} \mathrm{C}\right.$ NMR) spectrum [10]. NMR data were obtained with a Bruker AMX $400 \mathrm{MHz}$ Avance spectrometer (Billerica, MA, United States of America) operating at $9.4 \mathrm{~T}$ and using approximately $100 \mathrm{mg}$ of residue in a $4.0 \mathrm{~mm}$ rotor. The time between two consecutive pulses was $5.0 \mathrm{~s}$, and acquisitions were made at $15.0 \mathrm{~ms}$. Sample spinning at the magic angle was conducted at a frequency of $12.0 \mathrm{kHz}$ and a contact time of 2,000 $\mu \mathrm{s}$. The techniques of cross polarization/magic-angle spinning (CP-MAS) were used in all sequences. The reference at 0 ppm was set using $\mathrm{Si}\left(\mathrm{CH}_{3}\right)_{4}$.

Nitrogen adsorption-desorption experiments were performed to obtain initial information on the specific surface area of the apple pomace sample and its porous network. They were performed at $77 \mathrm{~K}$ using a NOVA surface analyzer from Quantachrome Instruments. About $150 \mathrm{mg}$ of the sample was outgassed at $423 \mathrm{~K}$ for $24 \mathrm{~h}$ under a residual 
pressure of 0.1 Pa. Data were recorded for relative vapor pressures from 0.0116 to 0.0984 . The specific surface area was determined using the Barret, Joyner and Halenda (BJH) method based on the cross-sectional area of nitrogen $\left(0.163 \mathrm{~nm}^{2}\right)$ at $77 \mathrm{~K}$ [21].

The point of zero charge $\left(\mathrm{pH}_{\mathrm{PZC}}\right)$ of the apple pomace sample was determined using the batch system equilibrium method [22], by adding $50 \mathrm{~mL}$ of $0.01 \mathrm{~mol} \mathrm{~L}{ }^{-1} \mathrm{KNO}_{3}$ with a previously adjusted initial $\mathrm{pH}$ (i.e., the $p H_{i}$ values of the solutions were adjusted from 2.0 to 12.0 with $0.10 \mathrm{~mol} \mathrm{~L}{ }^{-1}$ of $\mathrm{KOH}$ or $\mathrm{HNO}_{3}$ ) to several $100 \mathrm{~mL}$ flasks containing $0.10 \mathrm{~g}$ of adsorbent. The flasks were shaken at a rate of $150 \mathrm{rpm}$ using a thermostatic water bath shaker at a constant temperature of $25^{\circ} \mathrm{C}$, and the subsamples were then allowed to equilibrate for 24 h. Next, the suspensions were filtered and the final $\mathrm{pH}\left(p H_{f}\right)$ values of the solutions were recorded using a Digimed DM-20 pH meter (São Paulo, SP, Brazil). The value of $\mathrm{pH}_{\mathrm{PZC}}$ is the point where the curve of $\Delta p H\left(p H_{i}-p H_{f}\right) v s . p H_{i}$ crosses the line equal to zero [23].

\subsection{Adsorption experiments}

The adsorption experiments were performed in a Dist multiple spindle stirrer (Florianópolis, SC, Brazil) using $50 \mathrm{~mL}$ of MB dye solution for $5 \mathrm{~h}$. The suspensions were subsequently centrifuged using a microprocessed digital centrifuge Nova Tecnica NT 820 (Piracicaba, SP, Brazil) at 5,500 $\mathrm{rpm}$ for $10 \mathrm{~min}$ to separate the apple pomace from the aqueous solutions. The $\mathrm{pH}$ values of the solutions were adjusted with $1.0 \mathrm{~mol} \mathrm{~L}^{-1}$ of $\mathrm{NaOH}$ or $\mathrm{HCl}$.

The initial and final concentrations of the $\mathrm{MB}$ remaining in the solutions were determined by visible spectrophotometry using a Thermo Scientific Evolution 60 spectrophotometer (Waltham, MA, United States of America) fitted with a quartz cell with a path length of $1.0 \mathrm{~cm}$. Absorbance measurements were made at $665 \mathrm{~nm}$ (i.e., the maximum 
wavelength of MB dye). A calibration curve was constructed with dye concentrations ranging from 1.0 to $16.0 \mathrm{mg} \mathrm{L}^{-1}\left(R^{2}=0.9979\right)$.

The removal percentage $(R \%)$, the amount of MB adsorbed at time $t\left(q_{t}, \mathrm{mg} \mathrm{g}^{-1}\right)$, and the adsorption capacity at equilibrium $\left(q_{e}, \mathrm{mg} \mathrm{g}^{-1}\right)$ were calculated by applying Eqs. (1), (2) and (3), respectively:

$R \%=\frac{\left(C_{0}-C_{t}\right)}{C_{0}} \times 100$

$q_{t}=\frac{\left(C_{0}-C_{t}\right)}{m} \times V$

$q_{e}=\frac{\left(C_{0}-C_{e}\right)}{m} \times V$

where $C_{0}, C_{t}$ and $C_{e}$ are the concentrations of $\mathrm{MB}$ initially, at time $t$ and at equilibrium, respectively $\left(\mathrm{mg} \mathrm{L}^{-1}\right) ; m$ is the weight of apple pomace $(\mathrm{g})$; and $V$ is the volume of the MB dye solution (L).

Detailed description of equilibrium, thermodynamics, kinetics and statistical design of experiments can be found in the Supplementary Material (see S 2.3.1 - S 2.3.4).

\subsection{Desorption and reusability of the adsorbent}

To evaluate the reusability of the apple pomace after MB adsorption, five regeneration cycles were performed. Adsorption tests were performed with $50 \mathrm{~mL}$ of $\mathrm{MB}$ dye aqueous solution, and the values of $m, p H$ and $v$ were those obtained as optimal at the 
experimental design stage, with an initial MB concentration of $200 \mathrm{mg} \mathrm{L}^{-1}$ at $25{ }^{\circ} \mathrm{C}$ for 300 min. The dye desorption step was performed with ethanol, using the same values for adsorbent mass $(m)$ and stirring frequency $(v)$ as employed in the adsorption process. The $\mathrm{pH}$ and temperature $(T)$ values chosen were those that did not favor the adsorption process, in order to provide the highest possible desorption.

The experimental procedure was carried out in two stages to increase the concentration gradient and therefore the mass transfer flux involved, resulting in a greater MB dye removal. At each stage, the optimal mass of adsorbent was added to $50 \mathrm{~mL}$ of ethanol for 90 min, under the conditions described above. At the end of these procedures, the recovered apple pomace was filtered and dried in a forced air oven at $70{ }^{\circ} \mathrm{C}$ for $48 \mathrm{~h}$. Each experiment was performed in quadruplicate.

\section{RESULTS AND DISCUSSION}

\subsection{Characterization of the adsorbent}

\subsubsection{Elemental analysis}

The apple pomace showed high levels of carbon (46.71\%) and oxygen (46.34\%), and to a lesser extent hydrogen $(6.23 \%)$ and nitrogen $(0,72 \%)$. These results are very similar to those for other types of vegetable biomass, such as grape bagasse [10], and other apple pomace samples [24]. 


\subsubsection{FT-IR analysis}

The main absorption bands observed in the apple pomace FT-IR spectrum are shown in Figure 2, and the possible assignments are summarized in Table 1. These bands were also found in similar characterization analyses of apple pomace, pectin and cellulose [25-27]. The presence of several oxygenated functional groups is corroborated by the results obtained in the elemental analysis, where a high mass percentage was observed for oxygen.

\section{$3.1 .3^{13}$ C NMR analysis}

The solid-state ${ }^{13} \mathrm{C}$ NMR spectrum is shown in Fig. 3, and was very similar to that achieved by Wawer et al. and $\mathrm{Ng}$ et al. for apple peel samples $[28,29]$. The resonance peaks observed here are characteristic of structures present in the components of lignocellulosic materials, which include cellulose $(\mathrm{C})$, hemicellulose $(\mathrm{H})$, lignin $(\mathrm{L})$ and pectin $(\mathrm{P})$.

Through the analysis of Fig. 3, it is possible to observe several resonance peaks associated with the carbons of the glucose molecule (cellulose structure basic unit), such as those at 65 ppm (C-6), in the region between 68 and 80 ppm (C-2, C-3 and C-5), 83 ppm (C4) and $105 \mathrm{ppm}(\mathrm{C}-1)$. Values close to these chemical shifts were also found in the analysis of apple peel [29], rice husk [30] and grape pomace [10,31].

With regard to hemicellulose $(\mathrm{H})$, lignin $(\mathrm{L})$ and pectin $(\mathrm{P})$, the resonance peaks are related to their characteristic functional groups. In the case of hemicellulose $(\mathrm{H})$, the peaks between 0 and $45 \mathrm{ppm}$ and around $171 \mathrm{ppm}$ are related, respectively, to aliphatic carbons and carbonyl carbons, both present in the structure of acetate groups. These peaks can also be associated with the same structures present in pectin (P), since their constituent polysaccharides are similar to those of hemicellulose $(\mathrm{H})[29,30]$.

The structures related to the main components of lignin (L), on the other hand, are evidenced by the resonance peaks in the region between 115 and $150 \mathrm{ppm}$, typical of aromatic 
rings, as well as by the peak at $53 \mathrm{ppm}$, characteristic of methoxy groups [10,31]. This peak can also be associated with the same groups present in pectin (P) $[28,29]$.

The solid-state CP-MAS ${ }^{13} \mathrm{C}$ NMR spectrum of apple pomace was subdivided into nine distinct regions to perform semi-quantification of the main carbon types present in the chemical structure of the adsorbent [10]. These results are summarized in Table 2.

As can be seen, about $72 \%$ of the structures present in apple pomace are derived from alkyl O-carbons. Of these organic moieties, approximately $58 \%$ are related to hydroxyl groups present in the structures of cellulose $(\mathrm{C})$, hemicellulose $(\mathrm{H})$ and pectin $(\mathrm{P})$. In addition, oxygen is also present in $10.7 \%$ of the material in the form of methoxyl and carbonyl carbons. These results were corroborated by elemental analysis, which showed a relatively high mass percentage for the oxygen element. Finally, it is possible to observe a low content of aromatic structures in this type of agro-industrial residue.

\subsubsection{Specific surface area analysis}

The total specific surface area of the apple pomace pores obtained by the adsorption and desorption isotherms and by the BJH method was about $2.50 \mathrm{~m}^{2} \mathrm{~g}^{-1}$. This value is relatively small compared to other adsorbent materials such as activated carbon $\left(600-2000 \mathrm{~m}^{2}\right.$ $\mathrm{g}^{-1}$ ) [32], but similar to or larger than other agro-industrial residues used as adsorbents, such as grape $\left(2.0 \mathrm{~m}^{2} \mathrm{~g}^{-1}\right)[10]$ or apple $\left(0.71 \mathrm{~m}^{2} \mathrm{~g}^{-1}\right)$ pomaces [33].

\subsection{5 $\mathrm{pH}_{P Z C}$ determination}

The $\mathrm{pH}_{\mathrm{PZC}}$ curve for the apple pomace is shown in Fig. 4. This is the $\mathrm{pH}$ value at which there is equality between the positive and negative charges on the surface of a material, and based on these data, it is possible to describe the properties arising from the electrical double layer at the interface of a material under various $\mathrm{pH}$ conditions [34]. The value of 
$\mathrm{pH}_{\mathrm{PZC}}$ is determined at the intersection point of the curve, where $\Delta p H$ is zero, and is equal to 4.1. At $\mathrm{pH}$ values lower than $\mathrm{pH}_{\mathrm{PZC}}$, the adsorbent has a positive surface charge that promotes the adsorption of negatively charged compounds; conversely, when the $\mathrm{pH}$ is greater than $\mathrm{pH}_{\mathrm{PZC}}$, the adsorbent presents a negative surface charge that favors the adsorption of positively charged compounds, such as MB dye. It can therefore be concluded that the adsorption of this dye by apple pomace should be favored in media with a $\mathrm{pH}$ greater than 4.1.

\subsection{Effect of experimental conditions on the adsorption process}

\subsection{1 $2^{5}$ full factorial design with central point and effects of $T$ and $v$ on response variables}

Using the matrix in Table S2 (Supplementary Material), the results of the ANOVAs were generated to determine the significance of the verified factors, as well as the interactions between them up to the third order, at a significance level of up to $95 \%$.

As can be observed from the Pareto charts (Fig. 5), all of the major effects were significant for both response variables $(p$ value $<0.05)$, with only one non-significant interaction effect of second order and four of third order for $q_{t}$, and two non-significant interaction effects of second order and three of third order for $R \%$. The curvature for each response variable was also evaluated, and was significant for both analyses ( $p$ value $<0.001$ in both cases), which implies that some of the effects may have a quadratic term in the regression model proposed for each response variable.

After $C_{0}, m$ and $p H$, the next major factor with the greatest absolute effect on the responses is $T$. As can be observed, this variable has a negative effect on both responses (Fig. 5), indicating that the higher the temperature, the lower the results for $q_{t}$ and $R \%$, and showing that the process is exothermic. The adsorption of organic compounds such as dyes is 
generally an exothermic process, because the chemical bonds that are established between these compounds and the adsorption sites of carbon-based materials, such as agro-industrial wastes, tend to become weaker with increasing temperature. A rise in temperature also increases the solubility of the MB dye in water, as well as the strength of the solute-solvent interaction forces, making adsorption more difficult. [35]. Similar effects have been found in other studies involving the adsorption of dyes by biomass [10,36,37]. Since the best results were obtained at lower temperatures, a value of $5{ }^{\circ} \mathrm{C}$ was used when performing the following steps.

Although the variable $v$ has the smallest effect on the responses, it is a very important parameter in adsorption because it influences the distribution of solute within the solution and the formation of a stagnant film around the adsorbent particles [35]. From the data in Fig. 5, it can be observed that $v$ has a positive effect on both response variables, which indicates that both $q_{t}$ and $R \%$ increase in value in systems where the stirring frequency is higher.

One possible explanation for this dependence is that when the stirring frequency is higher, the adsorbent particles are more dispersed, providing greater contact with the adsorbate molecules and thus facilitating adsorption [38,39]. This increase is usually small $[35,40]$, and may even be insignificant in some cases $[41,42]$. Since the best results for this variable were obtained at $450 \mathrm{rpm}$, this value was used to perform the following steps.

\subsection{2 $3^{3}$ full factorial design and effects of $C_{0}, m$ and $p H$ on response variables}

Using the three variables with the greatest effect in the $2^{5}$ full factorial design $\left(C_{0}, m\right.$ and $p H$ ), a planning matrix (Table S3 - Supplementary Material) and ANOVAs were constructed to determine the significance of these factors, both in linear and quadratic terms, and their second-order interactions, at a significance level of up to 95\%. Table S4 (Supplementary Material), shows the results of this planning for $q_{t}$ and $R \%$. 
As can be observed from the Pareto charts (Fig. 6), there is a quadratic dependence between some factors and response variables. The other main effects were significant for both response variables, with three non-significant interaction effects of second order for $q_{t}$ and seven for $R \%$.

Moreover, it can be verified that the factors $m(\mathrm{~L}), p H(\mathrm{~L})$ and the interactions between the linear terms of $m$ with $C_{0}$ and $p H$ have the greatest effects on $q_{t}$. This shows that the quadratic terms of these variables have weaker effects on the responses, thus indicating the existence of a slight curvature with little likelihood of well-marked high or low points outside the edges. For $R \%$, the greatest effects were observed in the linear and quadratic terms of $m, C_{0}(\mathrm{~L})$ and their interactions. The relatively high value for $m(\mathrm{Q})$ indicates the incidence of the sharpest optimum curvature for this factor [43]. These behaviors can also be verified on the response surfaces (Fig. 7).

A comparison of the effects shown in Fig. 6 and Fig. 7a demonstrates that there is a positive effect from $C_{0}$ on $q_{t}$; this can be explained by the existence of a higher concentration gradient of $\mathrm{MB}$ dye when $C_{0}$ is at its highest level, which increases the diffusive contribution to the mass transfer process $[44,45]$. However, the addition of more dye to the solution causes a decrease in $R \%$, as can be observed from Fig. $7 \mathbf{b}$. One of the causes for this behavior is the saturation of the adsorption sites, i.e. when it is no longer possible for the apple pomace to accumulate dye molecules on its surface [9]. At this stage, the adsorbed MB dye molecules also exert electrostatic repulsion on those still in solution, increasing the mass transfer resistance around the adsorbent particles [46].

An inverse relationship is observed for the variable $m$ : although it has a negative effect on $q_{t}$, its effect on $R \%$ is positive. A higher availability of adsorbent material means that there are more adsorption sites available, thus contributing to increased removal. However, this increase in removal rate means that the final concentration of dye in solution is lower, 
reducing the concentration gradient of $\mathrm{MB}$ dye in the liquid and solid phases and hence the driving force for the occurrence of mass transfer, which leads to a reduction in $q_{t}$. This is evidenced by the inverse mathematical relationship between the adsorption capacity and the mass of adsorbent used (Eq. (2)). In addition, larger amounts of adsorbent favor particle agglomeration, which may increase the size of the diffusional pathway and decrease the specific surface area $[11,37]$.

Fig. 7a shows that the highest value for $q_{t}$ is seen for the lowest value for $C_{0}$, and $m$ is also at its lowest level at this point. This indicates that the negative effect of adsorbent mass outweighs the positive effects of $C_{0}$ on $q_{t}$ when the solution contains a low concentration of dye. With a low amount of adsorbent, large amounts of dye tend to accumulate rapidly, even with a low concentration of adsorbate in the solution, thus maintaining a more effective concentration gradient throughout the process. This means that the diffusive contribution to the mass transfer process increases with $q_{t}$ in the same way as when $C_{0}$ is at its highest level. This also explains the decrease in $R \%$ shown in Fig. $7 \mathbf{b}$, when $m$ is at its highest level and $C_{0}$ at its lowest.

Variation in the value of the $p H$ variable has positive effects for both responses (Fig. 6), and indicates that adsorption is favored in media with a value of $p H$ close to 10.0. This is due to the behavior of the net charge at the material interface under various $p H$ conditions. For the $2^{5}$ full factorial design, in experiments where the $p H$ was at its lowest level (3.0), and below $\mathrm{pH}_{\mathrm{PZC}}$, there is a weak interaction and probably repulsion between the analyte and sorbent, which are both positively charged. In contrast, when $p H$ is a high level (10.0), electrostatic interaction can occur, favoring the adsorption of the organic MB cations onto the negatively charged apple pomace. The same explanation can be used in relation to the $3^{3}$ full factorial design, since even if all values of the initial $p H$ are above $\mathrm{pH}_{\mathrm{PZC}}$, higher values lead to a higher negative charge on the solid surface, thus favoring adsorption [47-49]. 
The influence of $p H$ on $q_{t}$ and $R \%$ can also be verified by analyzing the response surfaces constructed for this factor along with $m$, the variable with the strongest effect on the responses (Fig. 8). An increase in $p H$ improves both response variables, with less effect on $R \%$ than in $q_{t}$. Moreover, it can be seen that a high $p H$ makes the effect of $m$ on $q_{t}$ more evident. This is because at lower $p H$ values, the difference between the charges of the MB dye and the surface of the adsorbent is smaller, which becomes the interaction between the dye and adsorbent difficult. For $R \%$, the effects of $m$ overlap with those of $p H$, indicating that a large mass of adsorbent compensates for the adverse effects of lower $p H$ when the aim is to increase the removal rate.

\subsubsection{Optimization using a desirability function}

With the aim of finding the optimal points, the desirability function of Derringer and Suich [50] was applied to verify the best operating conditions, ensuring the fulfillment of desirability criteria for the answers involved. Table 3 presents the results of the multiresponse optimization process for the variables $C_{0}, m$ and $\mathrm{pH}$.

These results show that the optimal values for $C_{0}$ and $m$ are close to the mean values used in planning, which once again demonstrates their contradictory behaviors regarding the response variables, as observed and discussed above. This is not the case for $p H$, for which the best operating point is again found in basic media $(\mathrm{pH}=10.0)$.

\subsection{Adsorption equilibrium}

Adjustments to isotherm models from nonlinear regression analysis (S 2.3.1 Supplementary Material) are shown in Fig. 9, while the parameter values related to these models are summarized in Table 4. 
The results show that the Langmuir, Sips and Redlich-Peterson models give satisfactory values for $R^{2}$ and $\chi^{2}$, indicating a good regression fit. However, the values for the exponential constants of the Sips and Redlich-Peterson models ( $\beta S$ and $\beta R P$, respectively) were equal to or very close to unity, a condition in which these models are reduced to the Langmuir equation. It can therefore be stated that the Langmuir model gives the best fit to the experimental data for MB adsorption by apple pomace, indicating that this process occurs via the formation of a monolayer and that the sites of adsorption are energetically homogeneous.

Since the data are best suited to the Langmuir model, it is necessary to carry out an interpretation of the results for its parameters. The values of $K_{L}$ are related to the affinity between the adsorbent and adsorbate, corresponding to the equilibrium MB dye concentration when $q_{e}$ is equal to half of $q_{m}[51,52]$. Higher $K_{L}$ values indicate a greater interaction between the adsorbent-adsorbate pair, since the maximum adsorption capacity is reached at lower $C_{e}$ values, meaning that there are more adsorbed dye molecules in the adsorbent than in the solution. The $K_{L}$ values are essential in order to obtain the $R_{L}$ parameter, and are between 0 and 1, indicating that adsorption is favorable according to the conditions assumed by Langmuir, and follows this model. Similar behavior was reported by Banat et al. [53], Belalia et al. [54] and Miyah et al. [55].

The parameter $q_{m}$ is commonly used to compare various adsorbents at a given temperature. Table 5 shows the maximum adsorption capacity of different adsorbents used for $\mathrm{MB}$ dye removal at $25^{\circ} \mathrm{C}$. The value obtained for $q_{m}$ in this work is higher than those of other adsorbents produced with agro-industrial residues, such as eggshell, yellow passion fruit waste and olive pomace, and even some aluminosilicates such as pyrophyllite. Apple pomace is shown to be a good adsorbent for MB dye, although the result for $q_{m}$ is much lower than those obtained with activated carbon. However, the adsorbent used in this study does not require high temperatures during its processing or activation steps, meaning that this material 
has a lower operating cost than activated carbon. It would therefore be possible to use a larger amount of this residue to compensate for its lower adsorption capacity than activated carbon.

\subsection{Thermodynamics studies}

Thermodynamics experiments were performed at $278 \mathrm{~K}, 288 \mathrm{~K}, 298 \mathrm{~K}$ and $308 \mathrm{~K}$ at an initial MB dye concentration of $275 \mathrm{mg} \mathrm{L}^{-1}$. This value for the concentration was chosen due to its close proximity to the optimal value for this factor, calculated based on the desirability function $\left(274.95 \mathrm{mg} \mathrm{L}^{-1}\right)$. The results of the thermodynamic parameters are shown in Table 6. It is possible to observe that an increase in $\Delta G^{\circ}{ }_{a d s}$ occurs as the temperature increases, indicating a reduction in the spontaneity of the process under these conditions. This behavior is characteristic of exothermic processes, where an increase in temperature does not favor the process, as previously discussed. Similar results were found for the adsorption of MB by cucumber peel [56].

The value found for $\Delta H^{\circ}$ ads is less than zero, indicating that the adsorption process is exothermic. It magnitude is observed to be within the range predicted for physical adsorption, showing that the interactions between MB dye and apple pomace are of this nature. Akkaya and Güzel [56] and Kumar and Barakat [57] found similar values for this parameter in the adsorption of brilliant green and MB dye by cactus fruit and cucumber peels, respectively. The negative value for $\Delta S^{\circ}{ }_{a d s}$ indicates that there is a reduction in the randomness of the system, that is, a decrease in the disorder of the solid-solution interface, during adsorption. The negative value of $\Delta S^{\circ}{ }_{a d s}$ may also be due to the loss of at least one degree of freedom of the MB molecules after adsorption [58]. 


\subsection{Adsorption kinetics}

The kinetic parameters, which are helpful for the prediction of adsorption rate, give important information for designing and modeling the adsorption processes. To investigate the mechanism of adsorption various kinetic models have been suggested. In this study, pseudo-first-order, pseudo-second-order, Elovich (reaction models) and intraparticle diffusion models (S 2.3.3 - Supplementary Material) were investigated to find the best fit to the experimental data.

Adjustments to the reaction kinetic models were made based on nonlinear regression analysis, and are shown in Fig. 10, and the parameter values for these models are given in Table 7. The results show that the pseudo-second-order model gives the highest values for $R^{2}$ and the smallest values for $\chi^{2}$, indicating a good regression fit. This means that it is likely that both external and intraparticle diffusion steps control the total kinetics of the adsorption process $[39,59]$. The pseudo-second order model gives a good fit to the reaction model for most adsorption processes involving dyes [9].

The kinetic constant $k_{2}$ is interpreted as a timescale factor, and represents the speed with which the system reaches equilibrium. Higher values of $k_{2}$ indicate a shorter time to reach this condition, and vice versa. This parameter may or may not depend on the experimental conditions of the process, depending on the case, and both types of behavior have been reported in the literature [60]. As can be observed, the $k_{2}$ values for this study increase as $C_{0}$ decreases. Similar results were reported by Ferrero [61] for the adsorption of MB dye by various adsorbents from agro-industrial residues (hazelnut, pinewood and oak residues), by Miyah et al. [55] for the adsorption of MB dye onto walnut shells powder and by Dotto and Pinto [39] for the adsorption of acid blue 9 and food yellow 3 dyes onto chitosan. 
Regarding the intraparticle regression model, all graphs show multilinearity, in two stages and with different inclinations, referring to intraparticle diffusion and equilibrium condition, since the external diffusion stage is significant only in the first moments of the adsorption process [62]. It can also be observed that the linear portion of the graph representing intraparticle diffusion does not pass through the origin, meaning that the adsorption process is controlled by both the diffusion in the stagnant film layer and the intraparticle diffusion [63]. This behavior has been reported by Marrakchi et al. [64] and Cao et al. [65] who used chitin for MB removal from aqueous solutions.

The results given Table 7 also show that the first linear portion of the graph, which represents the intraparticle diffusion stage, gave satisfactory values for $R^{2}$ and $\chi^{2}$, thus indicating a good regression fit. The value of $k_{i n t}$ also increases as $C_{0}$ increases; this is as expected, since a higher concentration gradient means that the driving force of adsorption processes is increased, favoring the diffusion of MB molecules into the adsorbent particles [66].

\subsection{Adsorption mechanism}

Based on the data set discussed in this work, it was possible to outline that the MB dye removal by the apple pomace sample occurs mainly due to electrostatic interactions, which is evidenced by the increase of $q_{t}$ values in $\mathrm{pH}$ values above $\mathrm{pH}_{\mathrm{PZC}}$. Similar conclusions were reported by other authors who investigated the adsorption of MB by agro-industrial wastes [67].

Moreover, apple pomace presents in its composition several oxygenated functional groups, such as $-\mathrm{COOH},-\mathrm{OCH}_{3},-\mathrm{CO}$ and $-\mathrm{OH}$, which can also interact with $\mathrm{MB}$ molecules through dipole-dipole forces. The incidence of aromatic rings, both in the chemical structure 
of apple pomace as in the MB dye molecules, can also favor $\pi$ - $\pi$ interactions, contributing to the adsorption process $[21,32,54]$.

Finally, the value found for $\Delta H^{\circ}{ }_{a d s}\left(-19,84 \pm 1,94 \mathrm{~kJ} \mathrm{~mol}^{-1}\right)$ indicates that these interactions are physical in nature, with no sharing or exchange of electrons. This reinforces the idea that the adsorption process can be reversed, at least in part, which is very interesting from an economic and environmental point of view.

\subsection{Desorption and reusability of the adsorbent}

The apple pomace was saturated with MB dye, and a desorption study was carried out to investigate the possibility of reusing this adsorbent. The results are shown in Fig. 11. In general, it can be seen that the equilibrium adsorption capacity decreases with each reuse, with the first use involving pomace in natura.

An evaluation of the reuse cycles shows that the experimental value found for $q_{e}$ decreases with each use of the adsorbent, with the largest decrease from the first to the second use (around 16\%), followed by a smaller decrease in the next step (approximately 5\%) and lower values still until the sixth reuse (around 1.5\%). The difference between the first and sixth use is approximately $23 \%$, which indicates that apple pomace can be regenerated at least five times for MB removal.

These results reveal that even after the two stages of desorption, there are still MB molecules that remain bound to apple pomace due to what some authors call "irreversible adsorption" $[68,69]$. Most of the desorption of $\mathrm{MB}$ is due to the replacement of the dye molecules by $\mathrm{H}_{3} \mathrm{O}^{+}$ions on the surface of the adsorbent, since recovery was performed in an acid medium, an adverse condition for adsorption [70].

The presence of MB after regeneration indicates that its interaction with apple pomace is not only due to electrostatic interactions, but also those described in adsorption 
mechanism, especially in the first reuse [71]. As the adsorbent is reused, these sites tend to deplete, making the differences in $q_{e}$ smaller. Similar results were found by these authors for the recovery of ethanol-modified sugarcane bagasse in an acid medium after adsorption of both crystal violet (a basic dye) and MB.

\section{CONCLUSIONS}

Based on the results obtained in this work, several conclusions can be drawn. The initial characterization analyses indicated the presence of several oxygenated functional groups in the chemical structure of apple pomace, primarily due to the hydroxyl groups present in cellulose, hemicellulose and pectin, which are the main basic components of this residue.

Through an analysis of the factorial designs, it was verified that all the evaluated experimental parameters had a significant influence on the observed responses. It was also possible to determine the values for each factor that produced the best results for each required response, thus indicating the best operating conditions for this process. These values were an initial $\mathrm{MB}$ concentration of $274.95 \mathrm{mg} \mathrm{L}^{-1}$, a mass of apple pomace of $84.7 \mathrm{mg}$, an initial $\mathrm{pH}$ of 10.0, a stirring rate of $450 \mathrm{rpm}$ and a temperature of $5{ }^{\circ} \mathrm{C}$.

For adsorption equilibrium, the Langmuir model was found to give the best fit to the experimental data at all temperatures, indicating that the interaction between MB dye and apple pomace occurs in monolayers. The results for the Langmuir constant $\left(K_{L}\right)$ and maximum adsorption capacity $\left(q_{m}\right)$ ranged from 0.0951 to $0.1122 \mathrm{~L} \mathrm{mg}^{-1}$ and 97.60 to 133.15 $\mathrm{mg} \mathrm{g}^{-1}$, respectively, suggesting a higher affinity between adsorbent and adsorbate at lower temperatures. 
The thermodynamic parameters revealed that the process was spontaneous $\left(-0.59 \leq \Delta G_{a d s}^{\circ} \leq-2.52 \mathrm{~kJ} \mathrm{~mol}^{-1}\right)$, physical $\left(\Delta H_{a d s}^{\circ}=-19.84 \pm 1.94 \mathrm{~kJ} \mathrm{~mol}^{-1}\right)$ and exothermic, and that the randomness of the system decreases $\left(\Delta S_{a d s}^{\circ}=-62.72 \pm 6.62 \mathrm{~J} \mathrm{~mol}^{-1} \mathrm{~K}^{-1}\right)$. This feature offers a significant economic advantage, as it avoids the high operating costs required for high-temperature production.

The regression for the reaction kinetic models showed a better fit for the pseudosecond order model, indicating that the diffusion of dye in the stagnant film covering the particles and the intraparticle diffusion inside the pores are the steps that control the total kinetics process under most of the conditions investigated. This conclusion was corroborated by an analysis of $q_{t} v s . t^{1 / 2}$, in which none of the linear portions referring to intraparticle diffusion (second portion) passed through the origin. The results for the $k_{2}$ kinetic constant ranged from $5.36 \times 10^{-4}$ to $8.47 \times 10^{-3} \mathrm{~g} \mathrm{mg}^{-1} \mathrm{~min}^{-1}$, indicating that equilibrium is not reached within a short period.

Finally, the overall data led to the conclusion that apple pomace can be used as an effective adsorbent for the removal of $\mathrm{MB}$ and possibly other basic dyes with similar chemical structures. The use of agro-industrial residues as adsorbents is a promising and lowcost option, and can minimize the environmental impacts resulting from improper disposal.

\section{ACKNOWLEDGMENTS}

The authors would like to thank CAPES, CNPq and FAPERGS for their financial support, and Sumabrás do Brasil Indústria e Comércio de Sucos de Maçã Ltda for apple pomace supply. 
The NMR spectrometer is part of the National NMR Network (PTNMR) and is partially supported by Infrastructure Project $N^{\circ} 022161$ (co-financed by FEDER through COMPETE 2020, POCI and PORL and FCT through PIDDAC).

\section{REFERENCES}

[1] J. Liu, Q. Liu, H. Yang, Assessing water scarcity by simultaneously considering environmental flow requirements, water quantity, and water quality, Ecol. Indic. 60 (2016) 434-441. doi:10.1016/j.ecolind.2015.07.019.

[2] V. Jegatheesan, B.K. Pramanik, J. Chen, D. Navaratna, C.-Y. Chang, L. Shu, Treatment of textile wastewater with membrane bioreactor: A critical review, Bioresour. Technol. 204 (2016) 202-212. doi:10.1016/j.biortech.2016.01.006.

[3] V. Khandegar, A.K. Saroha, Electrocoagulation for the treatment of textile industry effluent - A review, J. Environ. Manage. 128 (2013) 949-963. doi:10.1016/j.jenvman.2013.06.043.

[4] K.A. Adegoke, O.S. Bello, Dye sequestration using agricultural wastes as adsorbents, Water Resour. Ind. 12 (2015) 8-24. doi:10.1016/j.wri.2015.09.002.

[5] W. Zhang, L. Dong, H. Yan, H. Li, Z. Jiang, X. Kan, H. Yang, A. Li, R. Cheng, Removal of methylene blue from aqueous solutions by straw based adsorbent in a fixed-bed column, Chem. Eng. J. 173 (2011) 429-436. doi:10.1016/j.cej.2011.08.001.

[6] M. Wainwright, Photobactericidal activity of methylene blue derivatives against vancomycin-resistant Enterococcus spp., J. Antimicrob. Chemother. 44 (1999) 823825. doi:10.1093/jac/44.6.823.

[7] H. Chen, G.L. Rubenthaler, E.G. Schanus, Effect of Apple Fiber and Cellulose on the Physical Properties of Wheat Flour, J. Food Sci. 53 (1988) 304-305. 
doi:10.1111/j.1365-2621.1988.tb10242.x.

[8] A. Miclescu, L. Wiklund, Methylene blue, an old drug with new indications?, in: Jurnalul Rom. Anestezie Ter. Intaensiva, Jurnalul Roman de Anestezie Terapie Intaensiva, 2010. http://urn.kb.se/resolve?urn=urn:nbn:se:uu:diva-128811.

[9] M.T. Yagub, T.K. Sen, S. Afroze, H.M. Ang, Dye and its removal from aqueous solution by adsorption: A review, Adv. Colloid Interface Sci. 209 (2014) 172-184. doi:10.1016/j.cis.2014.04.002.

[10] M. Antunes, V.I. Esteves, R. Guegan, J.S. Crespo, A.N. Fernandes, M. Giovanela, Removal of diclofenac sodium from aqueous solution by Isabel grape bagasse, Chem. Eng. J. 192 (2012) 114-121. doi:10.1016/j.cej.2012.03.062.

[11] T. Calvete, E.C. Lima, N.F. Cardoso, S.L.P. Dias, F.A. Pavan, Application of carbon adsorbents prepared from the Brazilian pine-fruit-shell for the removal of Procion Red MX 3B from aqueous solution-Kinetic, equilibrium, and thermodynamic studies, Chem. Eng. J. 155 (2009) 627-636. doi:10.1016/j.cej.2009.08.019.

[12] L. Meili, P.V.S. Lins, M.T. Costa, R.L. Almeida, A.K.S. Abud, J.I. Soletti, G.L. Dotto, E.H. Tanabe, L. Sellaoui, S.H.V. Carvalho, A. Erto, Adsorption of methylene blue on agroindustrial wastes: Experimental investigation and phenomenological modelling, $\begin{array}{llllll}\text { Prog. } & \text { Biophys. } & \text { Mol. } & \text { Biol. } & 141 & \text { (2019) }\end{array}$ doi:10.1016/J.PBIOMOLBIO.2018.07.011.

[13] A.A. Oyekanmi, A. Ahmad, K. Hossain, M. Rafatullah, Statistical optimization for adsorption of Rhodamine B dye from aqueous solutions, J. Mol. Liq. 281 (2019) 4858. doi:10.1016/J.MOLLIQ.2019.02.057.

[14] S. Shakoor, A. Nasar, Removal of methylene blue dye from artificially contaminated water using citrus limetta peel waste as a very low cost adsorbent, J. Taiwan Inst. Chem. Eng. 66 (2016) 154-163. doi:https://doi.org/10.1016/j.jtice.2016.06.009. 
[15] S. Rangabhashiyam, N. Anu, N. Selvaraju, Sequestration of dye from textile industry wastewater using agricultural waste products as adsorbents, J. Environ. Chem. Eng. 1 (2013) 629-641. doi:10.1016/j.jece.2013.07.014.

[16] B.B. Kist, C.E. dos Santos, C. Carvalho, R.R. Beling, Brazilian Apple Yearbook, Gaz. Ed. (2019) 56. http://www.editoragazeta.com.br/sitewp/wpcontent/uploads/2019/06/MAçâ_2019_DUPLA.pdf.

[17] F.T. Macagnan, L.R. dos Santos, B.S. Roberto, F.A. de Moura, M. Bizzani, L.P. da Silva, Biological properties of apple pomace, orange bagasse and passion fruit peel as alternative sources of dietary fibre, Bioact. Carbohydrates Diet. Fibre. 6 (2015) 1-6. doi:10.1016/J.BCDF.2015.04.001.

[18] M. Kennedy, D. List, Y. Lu, L.Y. Foo, R.H. Newman, I.M. Sims, P.J.S. Bain, B. Hamilton, G. Fenton, Apple Pomace and Products Derived from Apple Pomace: Uses, Composition and Analysis, in: H.F. Linskens, J.F. Jackson (Eds.), Anal. Plant Waste Mater., Springer Berlin Heidelberg, Berlin, Heidelberg, 1999: pp. 75-119. doi:10.1007/978-3-662-03887-1_4.

[19] P. Chand, A.K. Shil, M. Sharma, Y.B. Pakade, Improved adsorption of cadmium ions from aqueous solution using chemically modified apple pomace: Mechanism, kinetics, and thermodynamics, Int. Biodeterior. Biodegradation. 90 (2014) 8-16. doi:10.1016/j.ibiod.2013.10.028.

[20] G.S. Dhillon, S. Kaur, S.K. Brar, Perspective of apple processing wastes as low-cost substrates for bioproduction of high value products: A review, Renew. Sustain. Energy Rev. 27 (2013) 789-805. doi:10.1016/j.rser.2013.06.046.

[21] J. Bortoluz, F. Ferrarini, L.R. Bonetto, J. da Silva Crespo, M. Giovanela, Use of lowcost natural waste from the furniture industry for the removal of methylene blue by adsorption: isotherms, kinetics and thermodynamics, Cellulose. 27 (2020) 6445-6466. 
doi:10.1007/s10570-020-03254-y.

[22] I.. Smičiklas, S.. Milonjić, P. Pfendt, S. Raičević, The point of zero charge and sorption of cadmium (II) and strontium (II) ions on synthetic hydroxyapatite, Sep. Purif. Technol. 18 (2000) 185-194. doi:10.1016/S1383-5866(99)00066-0.

[23] L.R. Bonetto, F. Ferrarini, C. de Marco, J.S. Crespo, R. Guégan, M. Giovanela, Removal of methyl violet $2 \mathrm{~B}$ dye from aqueous solution using a magnetic composite as an adsorbent, J. Water Process Eng. 6 (2015) 11-20. doi:https://doi.org/10.1016/j.jwpe.2015.02.006.

[24] M.R.B. Guerrero, M. Marques da Silva Paula, M.M. Zaragoza, J.S. Gutiérrez, V.G. Velderrain, A.L. Ortiz, V. Collins-Martínez, Thermogravimetric study on the pyrolysis kinetics of apple pomace as waste biomass, Int. J. Hydrogen Energy. 39 (2014) 16619_ 16627. doi:10.1016/J.IJHYDENE.2014,06.012.

[25] H.J. Rha, I.Y. Bae, S. Lee, S.-H. Yoo, P.-S. Chang, H.G. Lee, Enhancement of antiradical activity of pectin from apple pomace by hydroxamation, Food Hydrocoll. 25 (2011) 545-548. doi:10.1016/J.FOODHYD.2010.08.010.

[26] X. Wang, Q. Chen, X. Lü, Pectin extracted from apple pomace and citrus peel by subcritical water, Food Hydrocoll. $38 \quad$ (2014) 129-137. doi:10.1016/J.FOODHYD.2013.12.003.

[27] L. Wang, J. Li, Adsorption of C.I. Reactive Red 228 dye from aqueous solution by modified cellulose from flax shive: Kinetics, equilibrium, and thermodynamics, Ind. Crops Prod. 42 (2013) 153-158. doi:10.1016/J.INDCROP.2012.05.031.

[28] J.K.T. Ng, Z.D. Zujovic, B.G. Smith, J.W. Johnston, R. Schröder, L.D. Melton, Solidstate 13C NMR study of the mobility of polysaccharides in the cell walls of two apple cultivars of different firmness, Carbohydr. Res. 386 (2014) 1-6. doi:10.1016/J.CARRES.2013.12.019. 
[29] I. Wawer, M. Wolniak, K. Paradowska, Solid state NMR study of dietary fiber powders from aronia, bilberry, black currant and apple, Solid State Nucl. Magn. Reson. 30 (2006) 106-113. doi:10.1016/J.SSNMR.2006.05.001.

[30] C.R. Teixeira Tarley, S.L. Costa Ferreira, M.A. Zezzi Arruda, Use of modified rice husks as a natural solid adsorbent of trace metals: characterisation and development of an on-line preconcentration system for cadmium and lead determination by FAAS, Microchem. J. 77 (2004) 163-175. doi:10.1016/j.microc.2004.02.019.

[31] N.V. Farinella, G.D. Matos, M.A.Z. Arruda, Grape bagasse as a potential biosorbent of metals in effluent treatments, Bioresour. Technol. 98 (2007) 1940-1946. doi:10.1016/J.BIORTECH.2006.07.043.

[32] I. Ali, M. Asim, T.A. Khan, Low cost adsorbents for the removal of organic pollutants from wastewater, J. Environ. Manage. $113 \quad$ (2012) 170-183. doi:10.1016/J.JENVMAN.2012.08.028.

[33] P. Chand, A.K. Shil, M. Sharma, Y.B. Pakade, Improved adsorption of cadmium ions from aqueous solution using chemically modified apple pomace: Mechanism, kinetics, and thermodynamics, Int. Biodeterior. Biodegradation. 90 (2014) 8-16. doi:10.1016/J.IBIOD.2013.10.028.

[34] B. van Raij, Determinação do ponto de carga zero em solos, Bragantia. 32 (1973) 337347. http://www.scielo.br/scielo.php?script=sci_arttext\&pid=S0006$87051973000100018 \& n r m=$ iso.

[35] G. Crini, P.-M. Badot, Application of chitosan, a natural aminopolysaccharide, for dye removal from aqueous solutions by adsorption processes using batch studies: A review of recent literature, Prog. Polym. Sci. $33 \quad$ (2008) 399-447. doi:10.1016/J.PROGPOLYMSCI.2007.11.001.

[36] M.A. Adebayo, L.D.T. Prola, E.C. Lima, M.J. Puchana-Rosero, R. Cataluña, C. 
Saucier, C.S. Umpierres, J.C.P. Vaghetti, L.G. da Silva, R. Ruggiero, Adsorption of Procion Blue MX-R dye from aqueous solutions by lignin chemically modified with aluminium and manganese, J. Hazard. Mater. 268 (2014) 43-50. doi:10.1016/J.JHAZMAT.2014.01.005.

[37] N.F. Cardoso, R.B. Pinto, E.C. Lima, T. Calvete, C. V. Amavisca, B. Royer, M.L. Cunha, T.H.M. Fernandes, I.S. Pinto, Removal of remazol black B textile dye from aqueous solution by adsorption, Desalination. $269 \quad$ (2011) 92-103. doi:10.1016/J.DESAL.2010.10.047.

[38] M. Suzuki, Adsorption engineering, Kodansha, Tokyo, 1990.

[39] G.L. Dotto, L.A.A. Pinto, Adsorption of food dyes acid blue 9 and food yellow 3 onto chitosan: Stirring rate effect in kinetics and mechanism, J. Hazard. Mater. 187 (2011) 164-170. doi:10.1016/J.JHAZMAT.2011.01.016.

[40] İ. Uzun, F. Güzel, Kinetics and thermodynamics of the adsorption of some dyestuffs and p-nitrophenol by chitosan and MCM-chitosan from aqueous solution, J. Colloid Interface Sci. 274 (2004) 398-412. doi:10.1016/J.JCIS.2004.02.022.

[41] İ. Uzun, Kinetics of the adsorption of reactive dyes by chitosan, Dye. Pigment. 70 (2006) 76-83. doi:10.1016/J.DYEPIG.2005.04.016.

[42] M. Doğan, Y. Özdemir, M. Alkan, Adsorption kinetics and mechanism of cationic methyl violet and methylene blue dyes onto sepiolite, Dye. Pigment. 75 (2007) 701713. doi:10.1016/J.DYEPIG.2006.07.023.

[43] D.C. Montgomery, Design and analysis of experiments, 5 th, John Wiley \& Sons, New York, 2001.

[44] J. Duan, R. Liu, T. Chen, B. Zhang, J. Liu, Halloysite nanotube-Fe3O4 composite for removal of methyl violet from aqueous solutions, Desalination. 293 (2012) 46-52. doi:10.1016/J.DESAL.2012.02.022. 
[45] R. Liu, B. Zhang, D. Mei, H. Zhang, J. Liu, Adsorption of methyl violet from aqueous solution by halloysite nanotubes, Desalination. 268 (2011) 111-116. doi:10.1016/J.DESAL.2010.10.006.

[46] B.H. Hameed, Equilibrium and kinetic studies of methyl violet sorption by agricultural waste, J. Hazard. Mater. 154 (2008) 204-212. doi:10.1016/J.JHAZMAT.2007.10.010.

[47] C.-H. Weng, Y.-F. Pan, Adsorption of a cationic dye (methylene blue) onto spent activated clay, J. Hazard. Mater. $144 \quad$ (2007) 355-362. doi:10.1016/J.JHAZMAT.2006.09.097.

[48] M.T. Yagub, T.K. Sen, H.M. Ang, Equilibrium, Kinetics, and Thermodynamics of Methylene Blue Adsorption by Pine Tree Leaves, Water, Air, Soil Pollut. 223 (2012) 5267-5282. doi:10.1007/s11270-012-1277-3.

[49] W. Zou, H. Bai, S. Gao, K. Li, Characterization of modified sawdust, kinetic and equilibrium study about methylene blue adsorption in batch mode, Korean J. Chem. Eng. 30 (2013) 111-122. doi:10.1007/s11814-012-0096-y.

[50] G. Derringer, R. Suich, Simultaneous-optimization of several response variables, J. Qual. Technol.12 (1980) 214-219.

[51] V.S. Mane, I. Deo Mall, V. Chandra Srivastava, Kinetic and equilibrium isotherm studies for the adsorptive removal of Brilliant Green dye from aqueous solution by rice husk ash, J. Environ. Manage. $84 \quad$ (2007) 390-400. doi:10.1016/J.JENVMAN.2006.06.024.

[52] J.S. Piccin, G.L. Dotto, L.A.A. Pinto, Adsorption isotherms and thermochemical data of FD\&C Red nÂltextdegree 40 binding by Chitosan, Brazilian J. Chem. Eng. 28 (2011) 295-304. http://www.scielo.br/scielo.php?script=sci_arttext\&pid=S010466322011000200014\&nrm=iso.

[53] F. Banat, S. Al-Asheh, L. Al-Makhadmeh, Evaluation of the use of raw and activated 
date pits as potential adsorbents for dye containing waters, Process Biochem. 39 (2003) 193-202. doi:10.1016/S0032-9592(03)00065-7.

[54] A. Belalia, A. Zehhaf, A. Benyoucef, Preparation of Hybrid Material Based of PANI with $\mathrm{SiO} 2$ and Its Adsorption of Phenol from Aqueous Solution, Polym. Sci. Ser. B. 60 (2018) 816-824. doi:10.1134/S1560090418060039.

[55] Y. Miyah, A. Lahrichi, M. Idrissi, A. Khalil, F. Zerrouq, Adsorption of methylene blue dye from aqueous solutions onto walnut shells powder: Equilibrium and kinetic studies, $\begin{array}{lllll}\text { Surfaces } \quad \text { and } & \text { Interfaces. }\end{array}$ doi:https://doi.org/10.1016/j.surfin.2018.03.006.

[56] G. Akkaya, F. Güzel, Application of some domestic wastes as new low-cost biosorbentes for removal of methylene blue: kinetic and equilibrium studies, Chem. Eng. Commun. 201 (2014) 557-578. doi:10.1080/00986445.2013.780166.

[57] R. Kumar, M.A. Barakat, Decolourization of hazardous brilliant green from aqueous solution using binary oxidized cactus fruit peel, Chem. Eng. J. 226 (2013) 377-383. doi:10.1016/J.CEJ.2013.04.063.

[58] M. Al-Ghouti, M.A.M. Khraisheh, M.N.M. Ahmad, S. Allen, Thermodynamic behaviour and the effect of temperature on the removal of dyes from aqueous solution using modified diatomite: A kinetic study, J. Colloid Interface Sci. 287 (2005) 6-13. doi:10.1016/J.JCIS.2005.02.002.

[59] Y.S. Ho, G. McKay, Pseudo-second order model for sorption processes, Process Biochem. 34 (1999) 451-465. doi:https://doi.org/10.1016/S0032-9592(98)00112-5.

[60] W. Plazinski, W. Rudzinski, A. Plazinska, Theoretical models of sorption kinetics including a surface reaction mechanism: A review, Adv. Colloid Interface Sci. 152 (2009) 2-13. doi:https://doi.org/10.1016/j.cis.2009.07.009.

[61] F. Ferrero, Dye removal by low cost adsorbents: Hazelnut shells in comparison with 
wood sawdust, J. Hazard. Mater. $142 \quad$ (2007) 144-152. doi:https://doi.org/10.1016/j.jhazmat.2006.07.072.

[62] V. Fierro, V. Torné-Fernández, D. Montané, A. Celzard, Adsorption of phenol onto activated carbons having different textural and surface properties, Microporous $\begin{array}{llll}\text { Mesoporous } & \text { Mater. } & 111 & \text { 276-284. }\end{array}$ doi:https://doi.org/10.1016/j.micromeso.2007.08.002.

[63] Y.-S. Ho, Removal of copper ions from aqueous solution by tree fern, Water Res. 37 (2003) 2323-2330. doi:https://doi.org/10.1016/S0043-1354(03)00002-2.

[64] F. Marrakchi, M.J. Ahmed, W.A. Khanday, M. Asif, B.H. Hameed, Mesoporousactivated carbon prepared from chitosan flakes via single-step sodium hydroxide activation for the adsorption of methylene blue, Int. J. Biol. Macromol. 98 (2017) 233239. doi:https://doi.org/10.1016/j.ijbiomac.2017.01.119.

[65] Y.-L. Cao, Z.-H. Pan, Q.-X. Shi, J.-Y. Yu, Modification of chitin with high adsorption capacity for methylene blue removal, Int. J. Biol. Macromol. 114 (2018) 392-399. doi:https://doi.org/10.1016/j.ijbiomac.2018.03.138.

[66] S.J. Allen, G. McKay, K.Y.H. Khader, Intraparticle diffusion of a basic dye during adsorption onto sphagnum peat, Environ. Pollut. 56 (1989) 39-50. doi:https://doi.org/10.1016/0269-7491(89)90120-6.

[67] R. Han, W. Zou, W. Yu, S. Cheng, Y. Wang, J. Shi, Biosorption of methylene blue from aqueous solution by fallen phoenix tree's leaves, J. Hazard. Mater. 141 (2007) 156-162. doi:https://doi.org/10.1016/j.jhazmat.2006.06.107.

[68] V. Vimonses, B. Jin, C.W.K. Chow, C. Saint, Enhancing removal efficiency of anionic dye by combination and calcination of clay materials and calcium hydroxide, J. Hazard. Mater. 171 (2009) 941-947. doi:10.1016/J.JHAZMAT.2009.06.094.

[69] J. Gómez-Pastora, E. Bringas, I. Ortiz, Recent progress and future challenges on the 
use of high performance magnetic nano-adsorbents in environmental applications, Chem. Eng. J. 256 (2014) 187-204. doi:10.1016/J.CEJ.2014.06.119.

[70] J. Liu, Q. Liu, H. Yang, Assessing water scarcity by simultaneously considering environmental flow requirements, water quantity, and water quality, Ecol. Indic. 60 (2016) 434-441. doi:10.1016/J.ECOLIND.2015.07.019.

[71] B.C.S. Ferreira, F.S. Teodoro, A.B. Mageste, L.F. Gil, R.P. de Freitas, L.V.A. Gurgel, Application of a new carboxylate-functionalized sugarcane bagasse for adsorptive removal of crystal violet from aqueous solution: Kinetic, equilibrium and thermodynamic studies, Ind. Crops Prod. $65 \quad$ (2015) 521-534. doi:10.1016/J.INDCROP.2014.10.020.

[72] T.W.G. Solomons, C.B. Fryhle, S.A. Snyder, Organic Chemistry, 12th ed., John Wiley \& Sons, Hoboken, 2016.

[73] D.L. Pavia, G.M. Lampman, G.S. Kriz, J.A. Vyvyan, Introduction to Spectroscopy, Cengage Learning, Belmont, 2014.

[74] R.M. Silverstein, F.X. Webster, D.J. Kiemle, D.L. Bryce, Spectrometric Identification of Organic Compounds, 8th ed., John Wiley \& Sons, Hoboken, 2014.

[75] T. Mimmo, C. Marzadori, D. Montecchio, C. Gessa, Characterisation of Ca- and Alpectate gels by thermal analysis and FT-IR spectroscopy, Carbohydr. Res. 340 (2005) 2510-2519. doi:10.1016/J.CARRES.2005.08.011.

[76] L. Wang, J. Li, Adsorption of C.I. Reactive Red 228 dye from aqueous solution by modified cellulose from flax shive: Kinetics, equilibrium, and thermodynamics, Ind. Crops Prod. 42 (2013) 153-158. doi:10.1016/J.INDCROP.2012.05.031.

[77] K.C. Bedin, A.C. Martins, A.L. Cazetta, O. Pezoti, V.C. Almeida, KOH-activated carbon prepared from sucrose spherical carbon: Adsorption equilibrium, kinetic and thermodynamic studies for Methylene Blue removal, Chem. Eng. J. 286 (2016) 476- 
484. doi:10.1016/J.CEJ.2015.10.099.

[78] W. Gan, X. Shang, X.-H. Li, J. Zhang, X. Fu, Achieving high adsorption capacity and ultrafast removal of methylene blue and $\mathrm{Pb} 2+$ by graphene-like TiO2@C, Colloids Surfaces A Physicochem. Eng. Asp. $561 \quad$ (2019) 218-225. doi:10.1016/J.COLSURFA.2018.10.079.

[79] D. Özer, G. Dursun, A. Özer, Methylene blue adsorption from aqueous solution by dehydrated peanut hull, J. Hazard. Mater. 144 (2007) 171-179. doi:10.1016/J.JHAZMAT.2006.09.092.

[80] H. Lata, V.K. Garg, R.K. Gupta, Removal of a basic dye from aqueous solution by adsorption using Parthenium hysterophorus: An agricultural waste, Dye. Pigment. 74 (2007) 653-658. doi:10.1016/J.DYEPIG.2006.04.007.

[81] K. Lu, T. Wang, L. Zhai, W. Wu, S. Dong, S. Gao, L. Mao, Adsorption behavior and mechanism of Fe-Mn binary oxide nanoparticles: Adsorption of methylene blue, J. Colloid Interface Sci. 539 (2019) 553-562. doi:10.1016/J.JCIS.2018.12.094.

[82] A. Gücek, S. Şener, S. Bilgen, M.A. Mazmanc1, Adsorption and kinetic studies of cationic and anionic dyes on pyrophyllite from aqueous solutions, J. Colloid Interface Sci. 286 (2005) 53-60. doi:10.1016/J.JCIS.2005.01.012.

[83] L. Mouni, L. Belkhiri, J.-C. Bollinger, A. Bouzaza, A. Assadi, A. Tirri, F. Dahmoune, K. Madani, H. Remini, Removal of Methylene Blue from aqueous solutions by adsorption on Kaolin: Kinetic and equilibrium studies, Appl. Clay Sci. 153 (2018) 3845. doi:10.1016/J.CLAY.2017.11.034.

[84] F.A. Pavan, E.C. Lima, S.L.P. Dias, A.C. Mazzocato, Methylene blue biosorption from aqueous solutions by yellow passion fruit waste, J. Hazard. Mater. 150 (2008) 703712. doi:10.1016/J.JHAZMAT.2007.05.023.

[85] F. Banat, S. Al-Asheh, R. Al-Ahmad, F. Bni-Khalid, Bench-scale and packed bed 
sorption of methylene blue using treated olive pomace and charcoal, Bioresour. Technol. 98 (2007) 3017-3025. doi:10.1016/J.BIORTECH.2006.10.023.

[86] W.T. Tsai, J.M. Yang, C.W. Lai, Y.H. Cheng, C.C. Lin, C.W. Yeh, Characterization and adsorption properties of eggshells and eggshell membrane, Bioresour. Technol. 97 (2006) 488-493. doi:10.1016/J.BIORTECH.2005.02.050. 


\section{FIGURE CAPTIONS}

Fig. 1. Chemical structure of MB.

Fig. 2. FT-IR spectrum of apple pomace.

Fig. 3. Solid-state CP-MAS ${ }^{13} \mathrm{C}$ NMR spectrum of apple pomace.

Fig. 4. Curve of the $\mathrm{pH}_{\mathrm{PZC}}$ of the apple pomace. Note: the horizontal dotted line shown is used only as a visual guide.

Fig. 5. Pareto plot of standardized effects of $2^{5}$ full factorial design: (a) $q_{t}$ and (b) $R \%$. Note: effects whose values are shown below with "NS" are not significant.

Fig. 6. Pareto plot of standardized effects of $3^{3}$ full factorial design: (a) $q_{t}$ and (b) $R \%$. Note: effects whose values are shown below with "NS" are not significant; (L) - linear effect; (Q) - quadratic effect.

Fig. 7. Response surface of the effects $C_{0}$ and $m$ for (a) $q_{t}$ and (b) $R \%$. Note: $\mathrm{pH}$ is at its optimal point.

Fig. 8. Response surface of the effects $m$ and $p H$ for (a) $q_{t}$ and (b) $R \%$. Note: $C_{0}$ is at its optimal point. 
Fig. 9. Adsorption isotherms of MB onto apple pomace. (a) Langmuir model, (b) Freundlich model, (c) Sips model, (d) Redlich-Peterson model. Adsorption experimental conditions: $m=84.7 \mathrm{mg}, p H=10.0, v=450 \mathrm{rpm}, T=298 \mathrm{~K}$.

Fig. 10. Kinetic models for the adsorption of MB onto apple pomace. Reaction models for (a) $C_{0}=100 \mathrm{mg} \mathrm{L}^{-1}$, (b) $C_{0}=200 \mathrm{mg} \mathrm{L}^{-1}$, (c) $C_{0}=100 \mathrm{mg} \mathrm{L}^{-1}$; Intraparticle diffusion model for (d) $C_{0}=100 \mathrm{mg} \mathrm{L}^{-1}$, (e) $C_{0}=200 \mathrm{mg} \mathrm{L}^{-1}$; and (f) $C_{0}=300 \mathrm{mg} \mathrm{L}^{-1}$. Adsorption experimental conditions: $m=84.7 \mathrm{mg}, p H=10.0 ; v=450 \mathrm{rpm} ; T=298 \mathrm{~K}$.

Fig. 11. Reusability cycles of apple pomace. Adsorption experimental conditions: $C_{0}=200 \mathrm{mg} \mathrm{L}^{-1}, m=84.7 \mathrm{mg}, p H=10.0, v=450 \mathrm{rpm}, T=298 \mathrm{~K}$. 


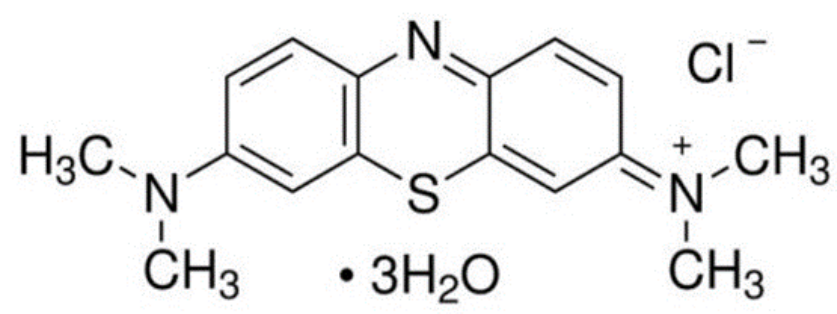

Fig. 1

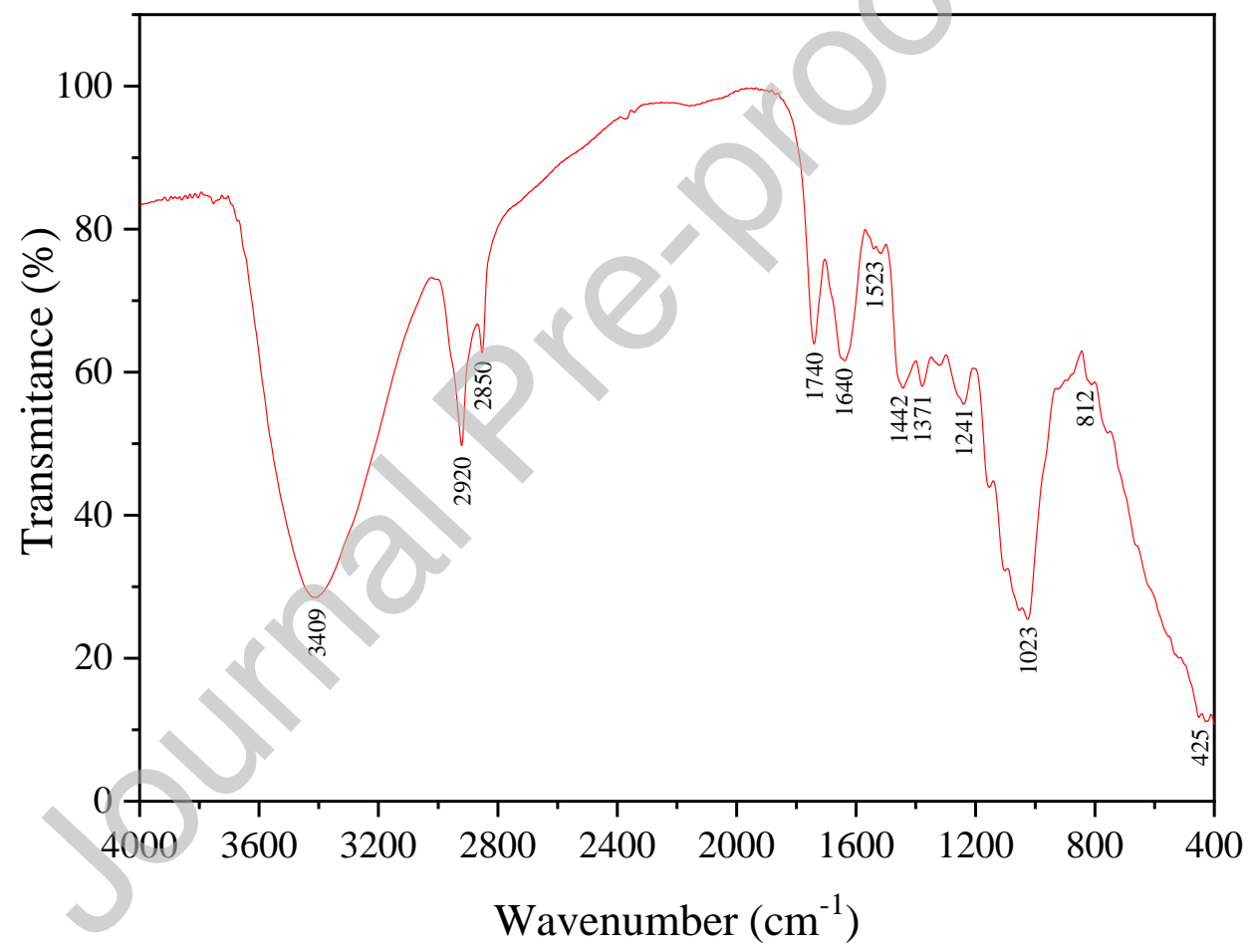

Fig. 2 
(C) - Cellulose

(H) - Hemicelullose

(L) - Lignin

(P) - Pectin

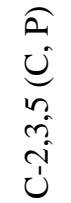

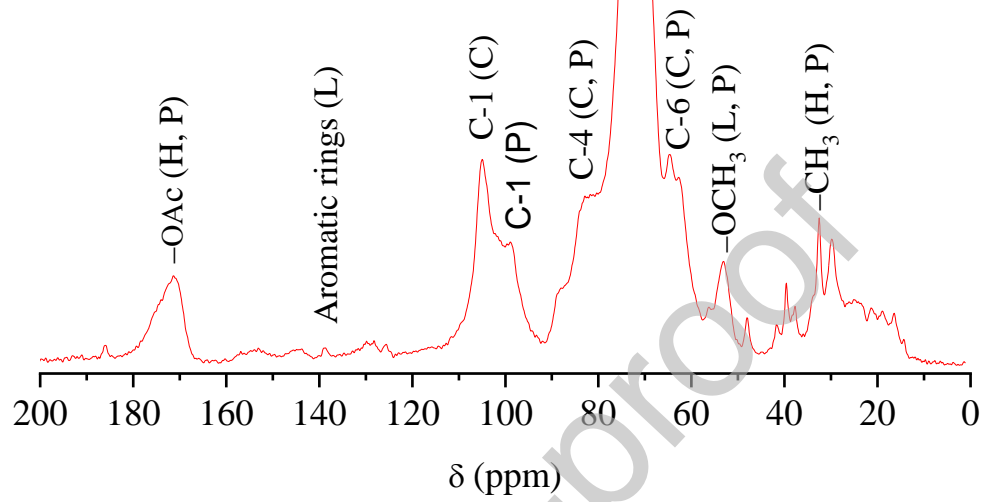

Fig. 3

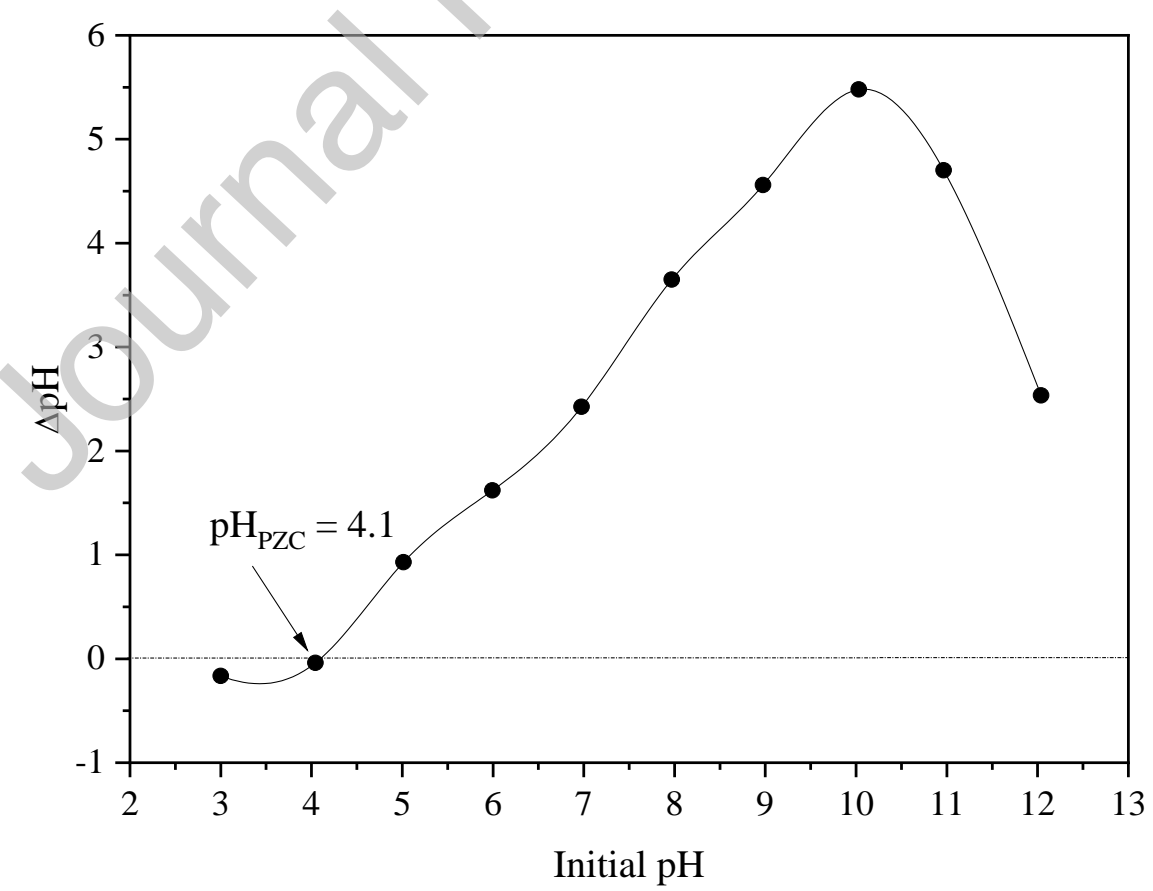

Fig. 4. 

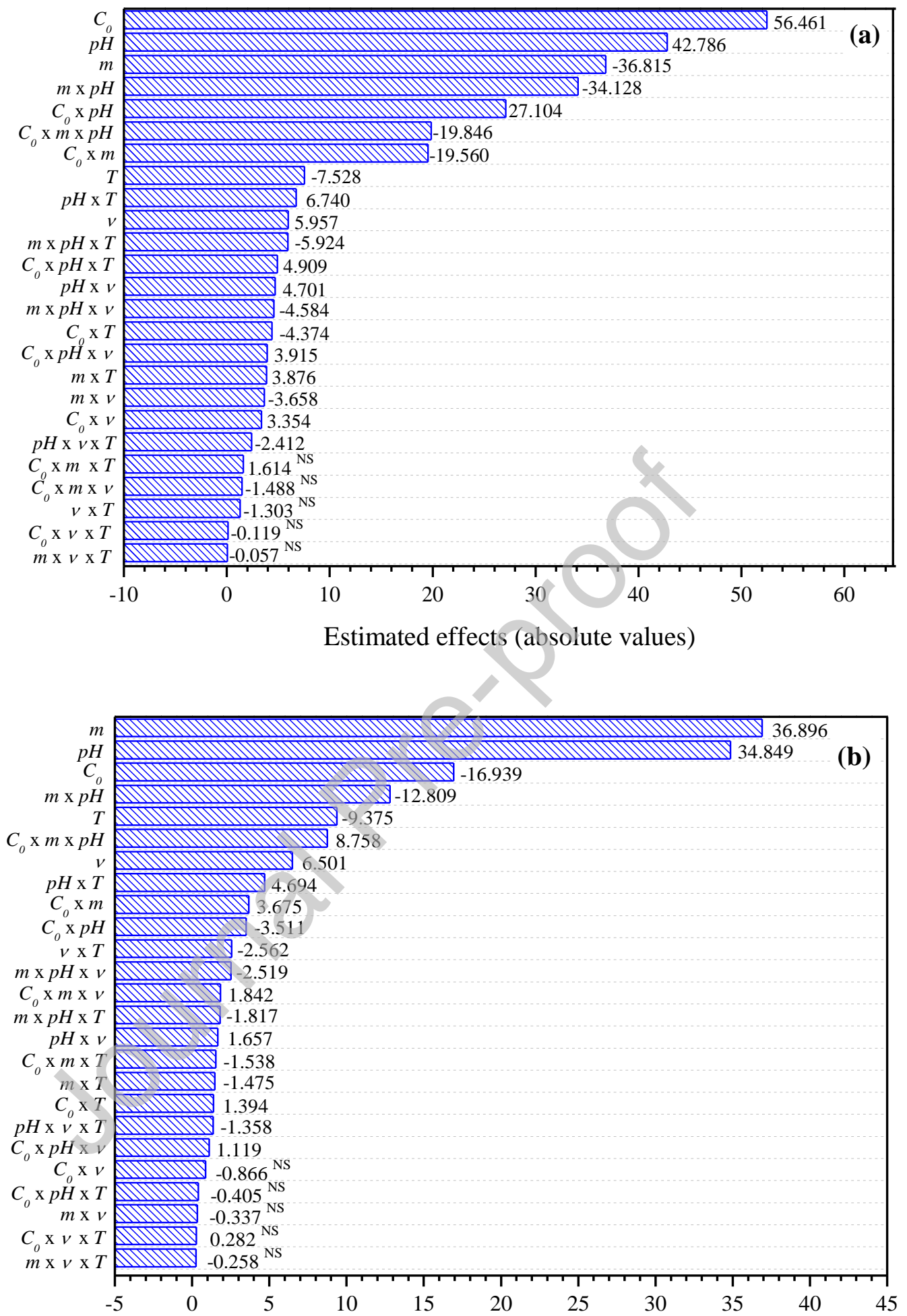

Estimated effects (absolute values)

Fig. 5. 


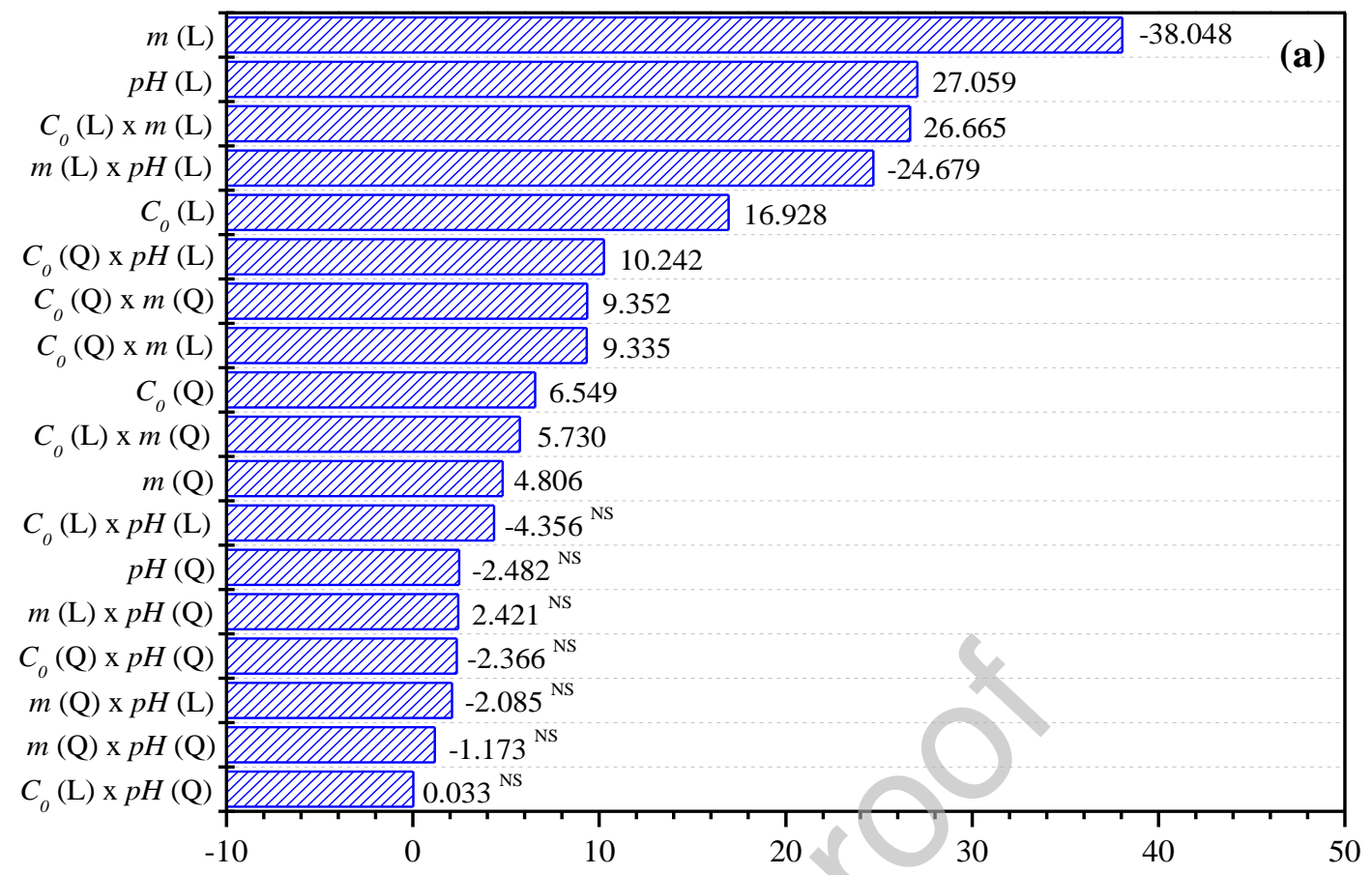

Estimated effects (absolute values)

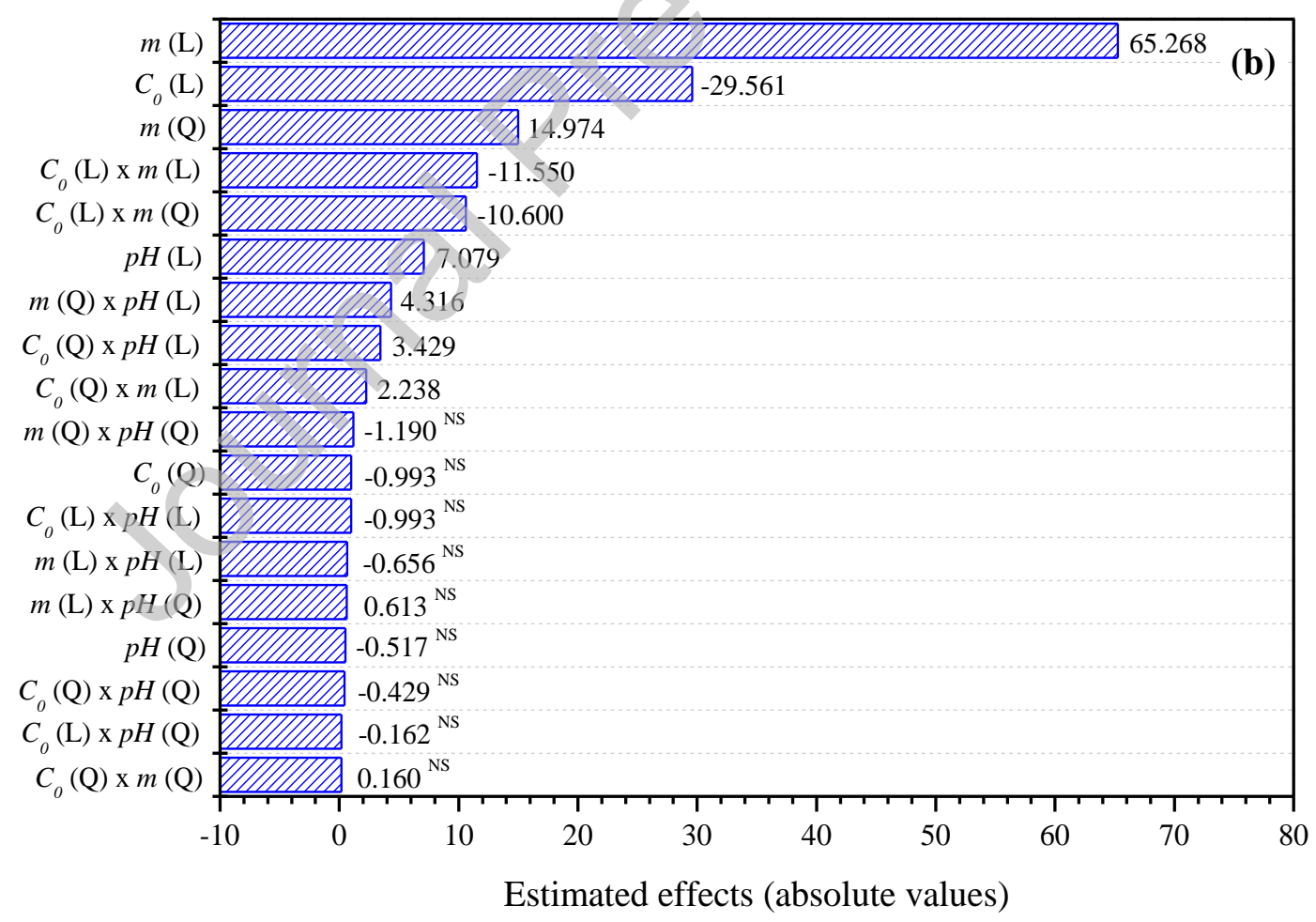

Fig. 6 

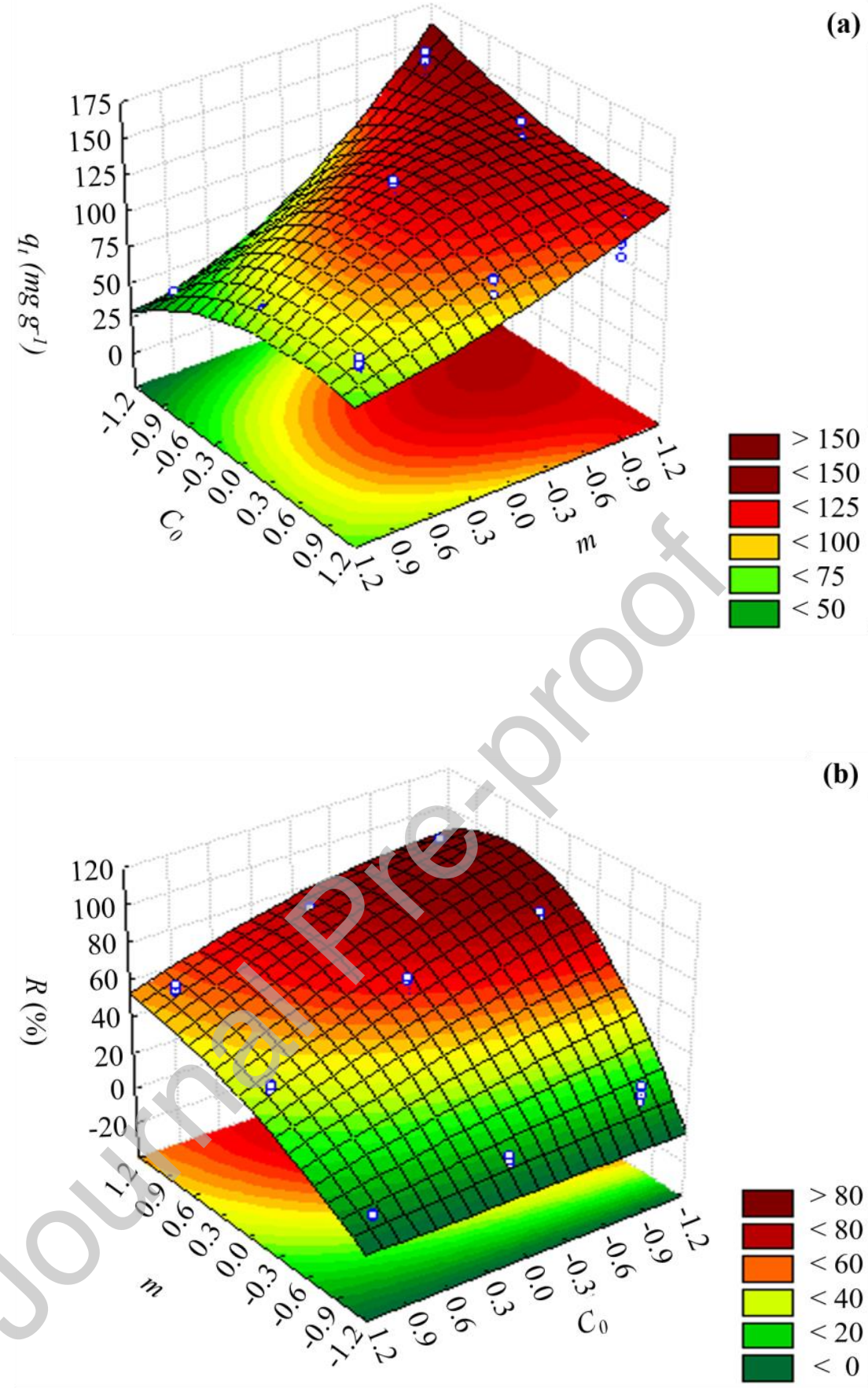

Fig. 7 

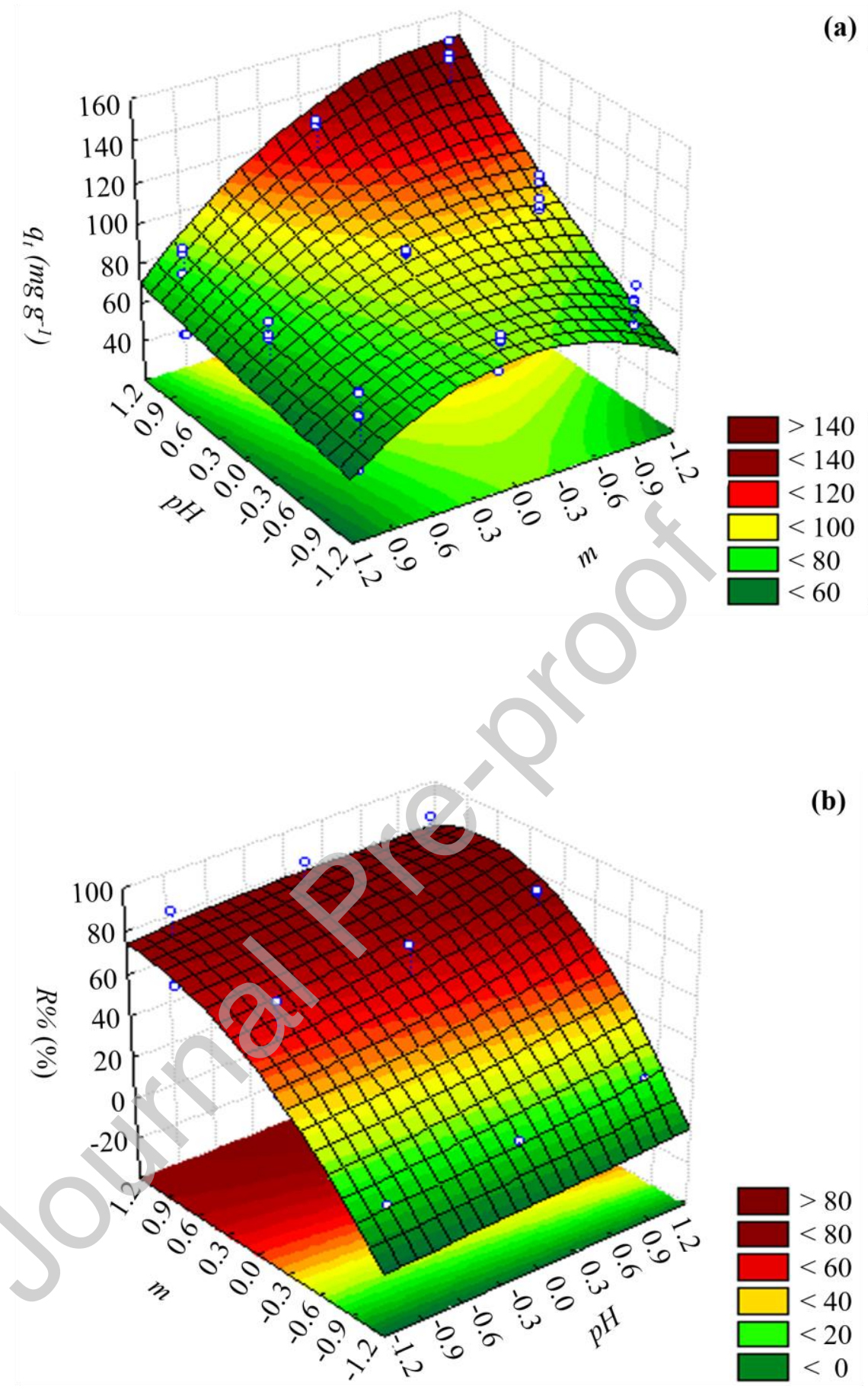

Fig. 8 

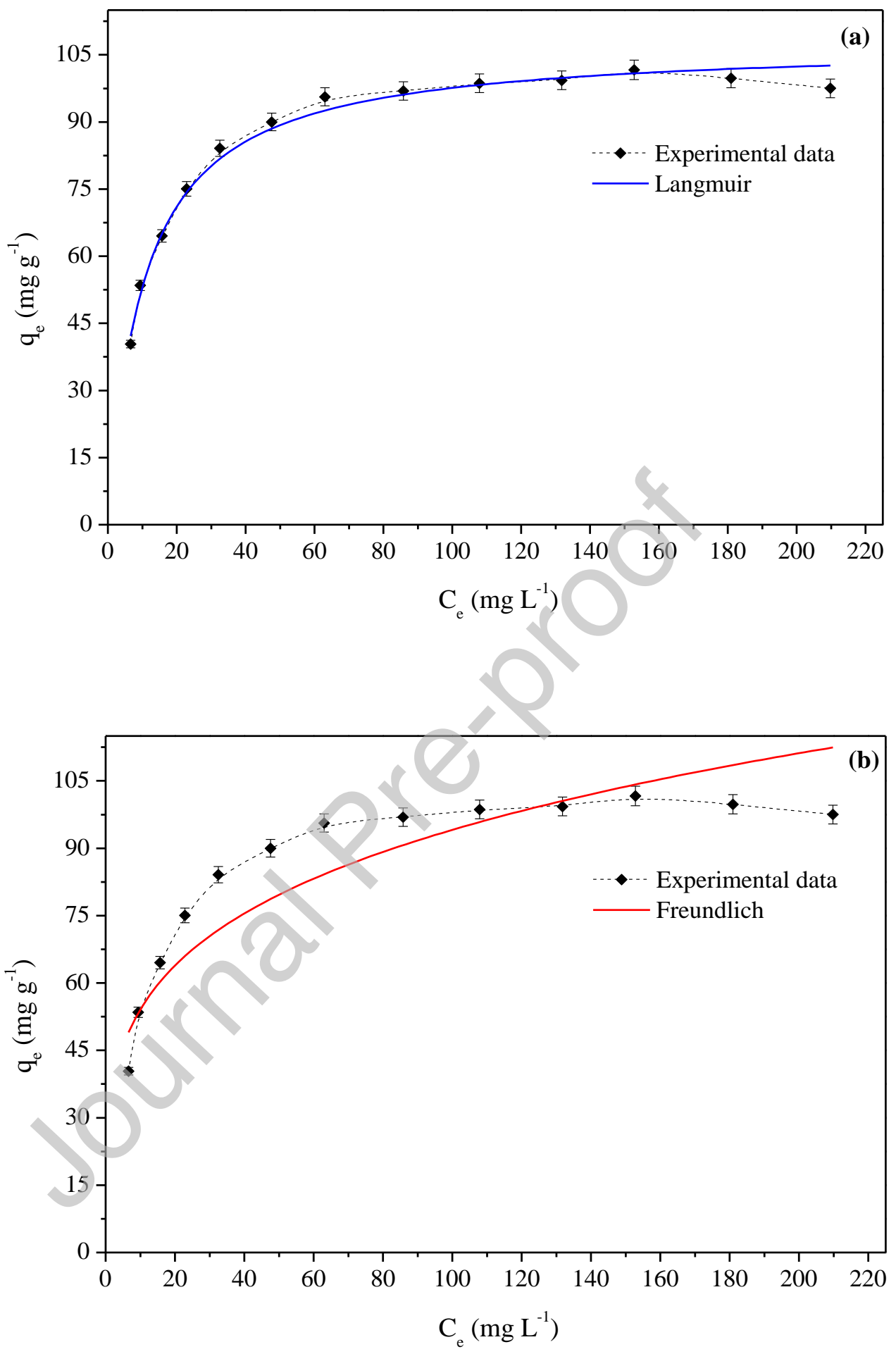

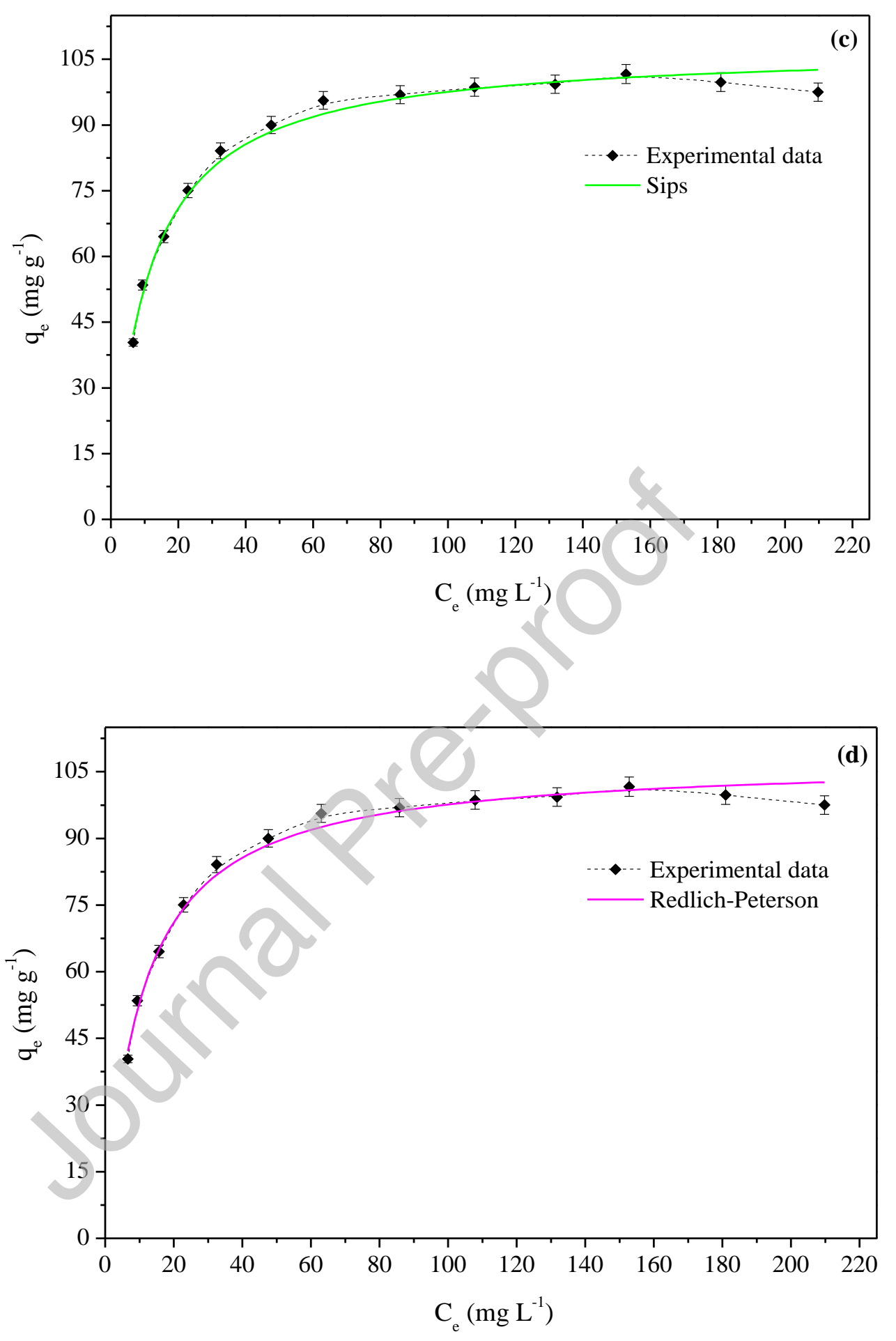

Fig. 9 

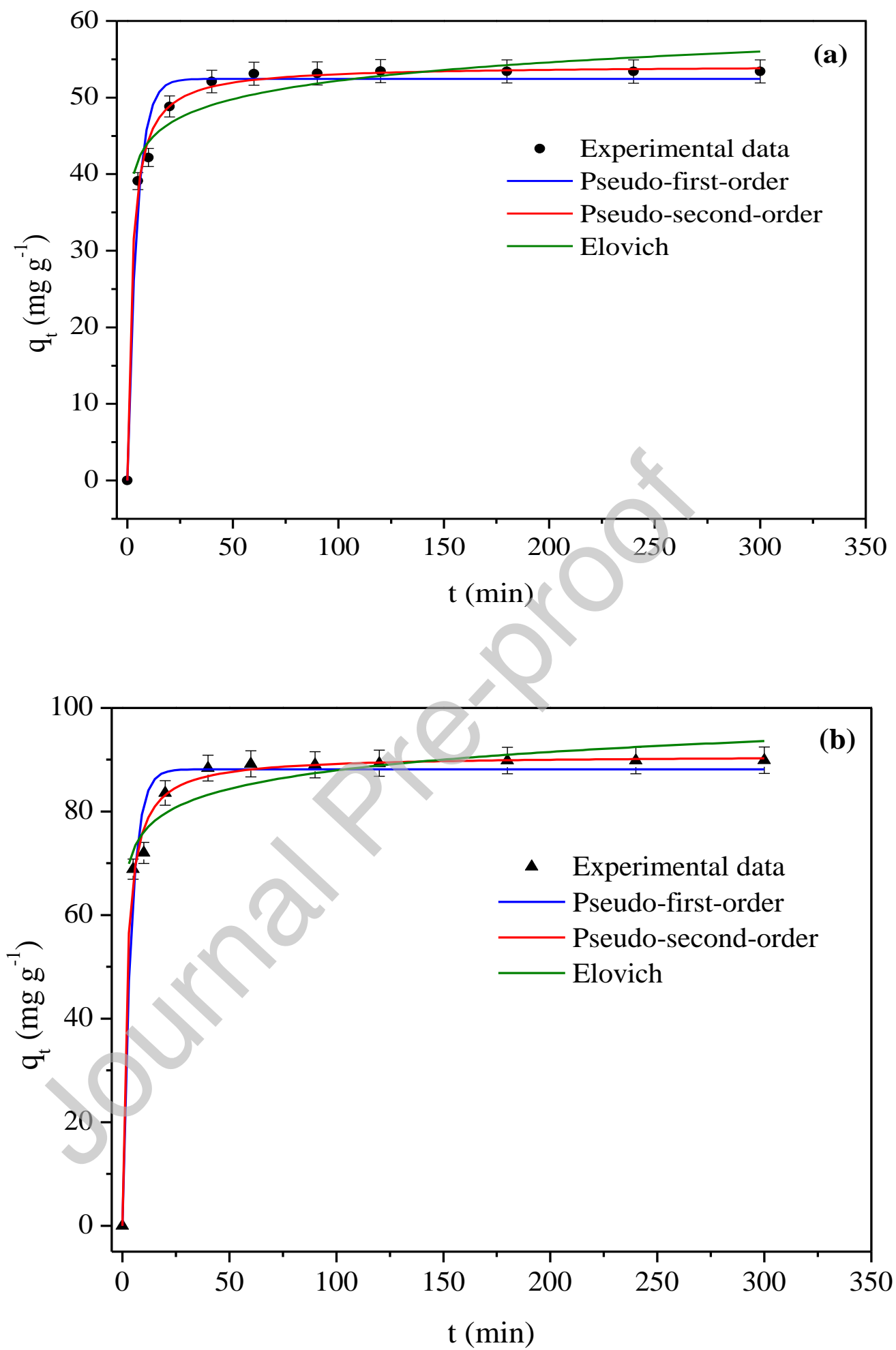

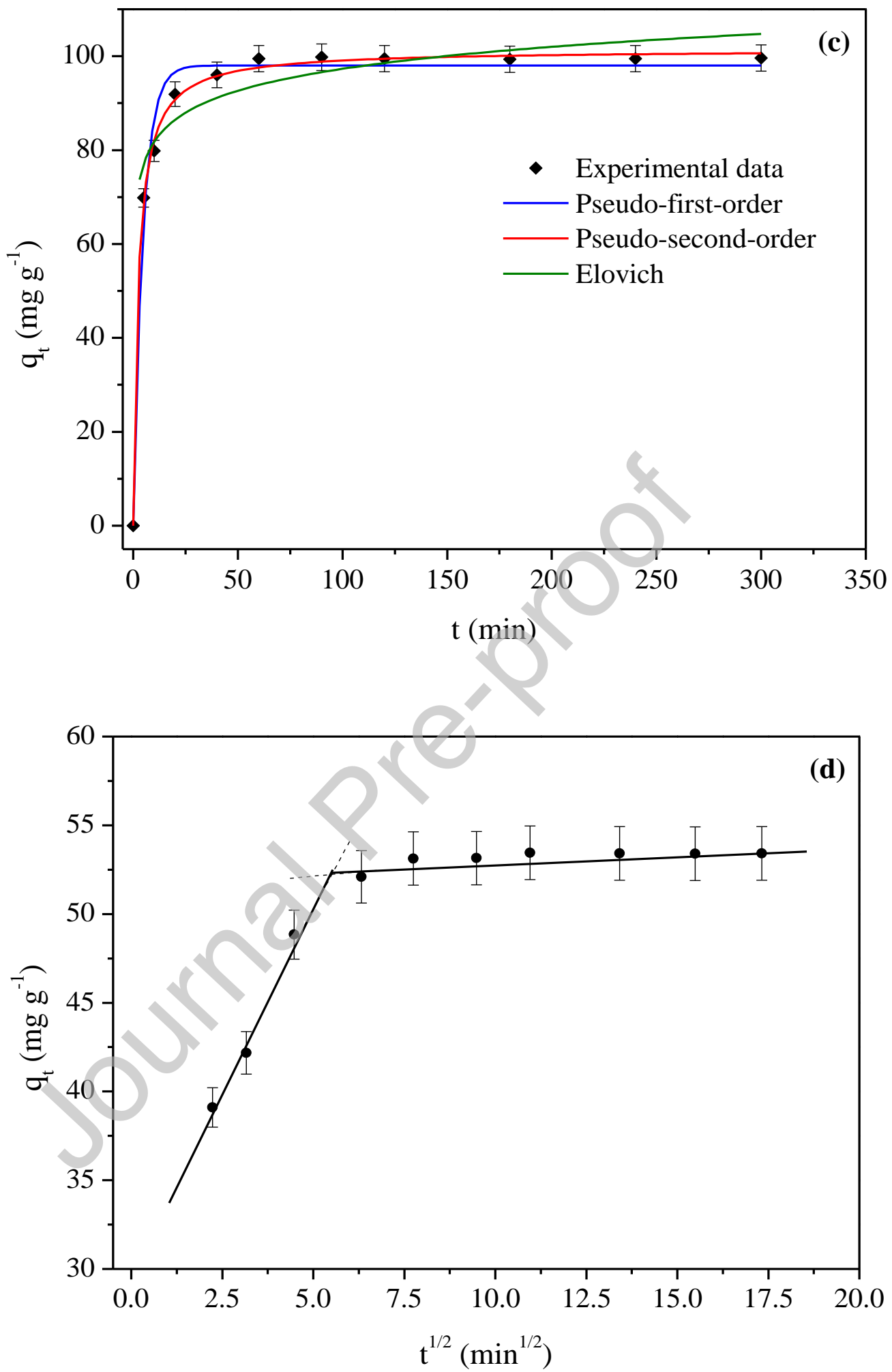

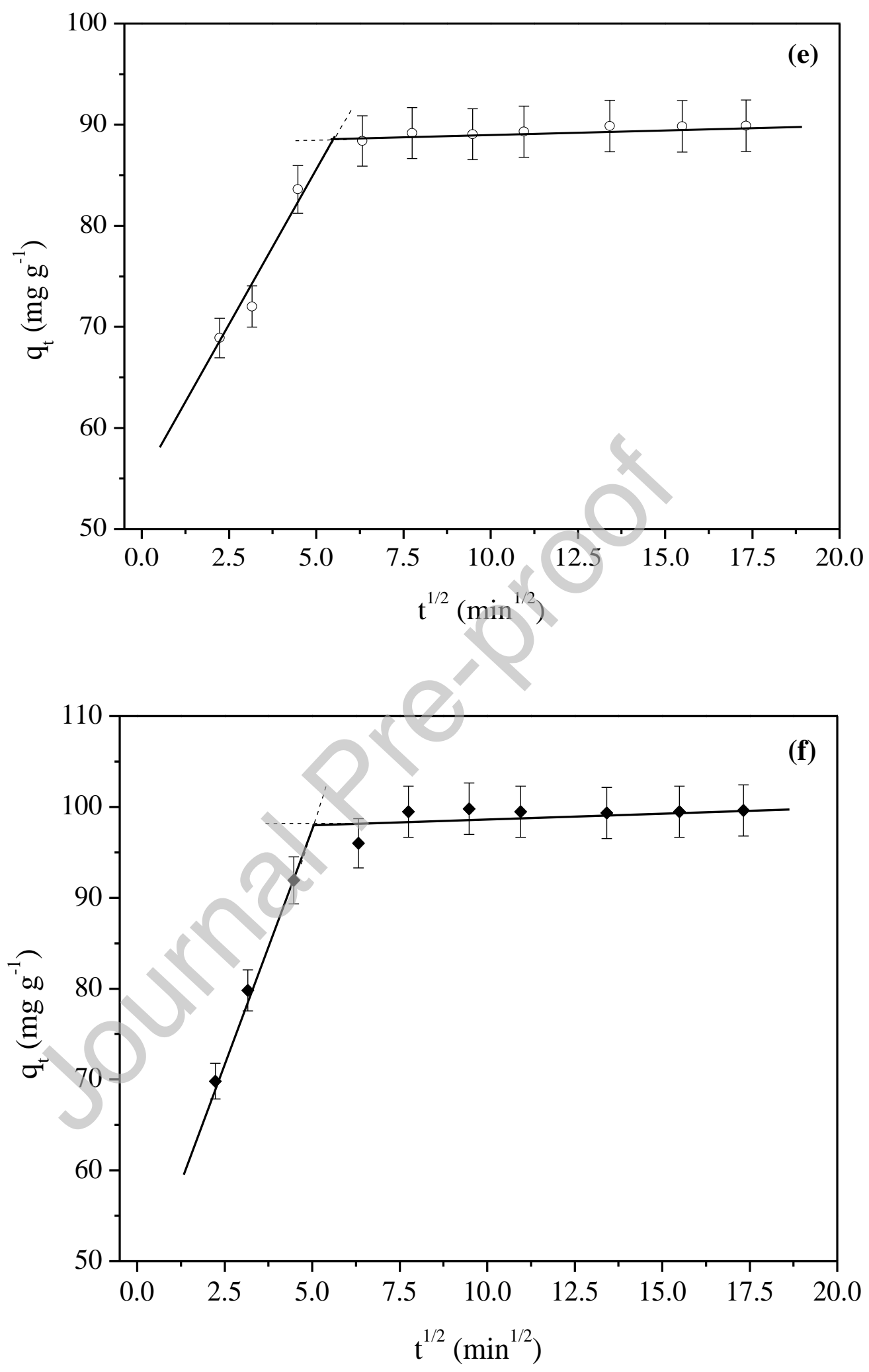

Fig. 10 


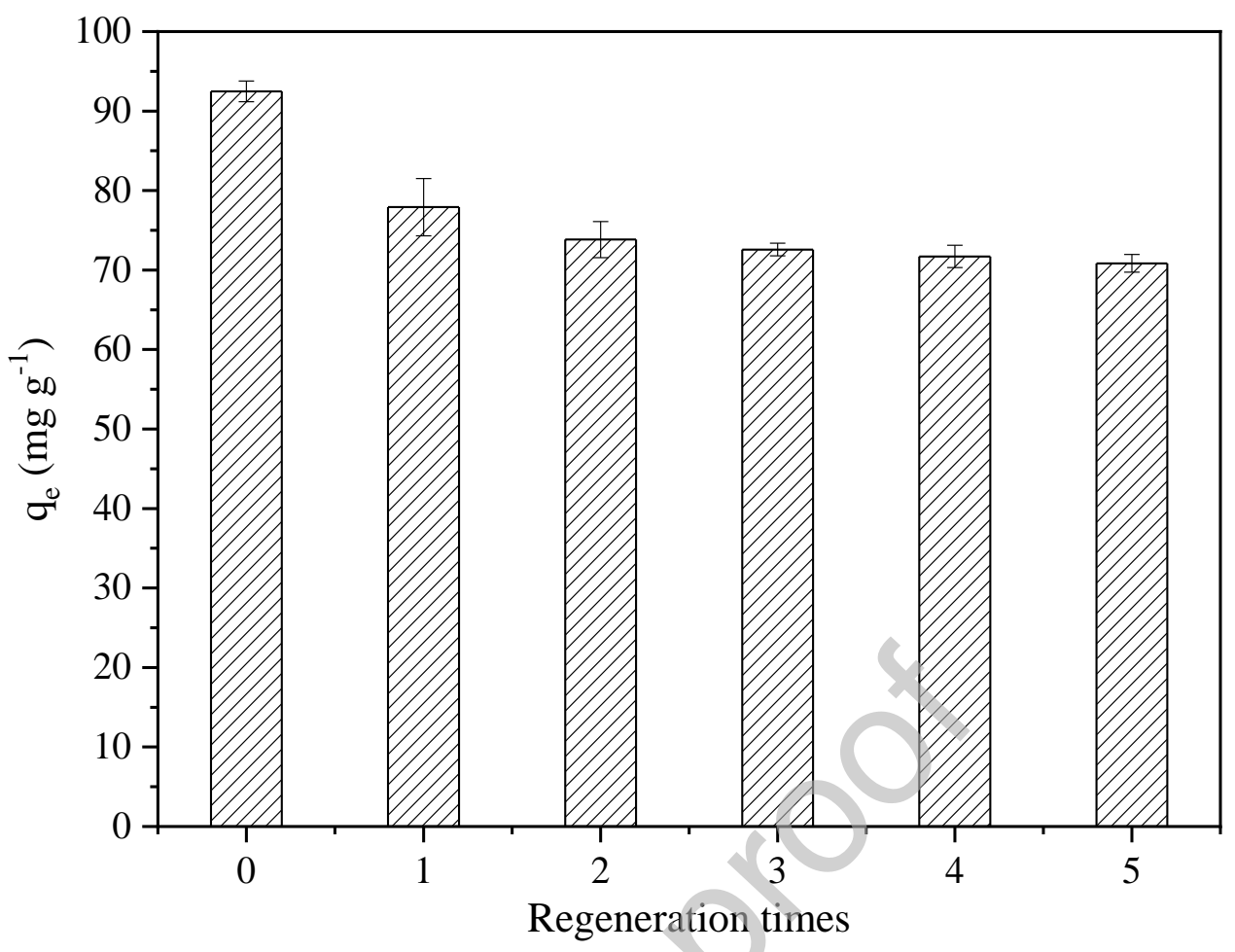

Fig. 11 


\section{TABLE CAPTIONS}

Table 1. Main bands observed in the FT-IR spectrum of apple pomace

\begin{tabular}{|c|c|c|}
\hline $\begin{array}{l}\text { Wavenumber } \\
\left(\mathrm{cm}^{-1}\right)\end{array}$ & Possible assignments & Reference \\
\hline 3409 & Symmetric $\mathrm{O}-\mathrm{H}$ and $\mathrm{N}-\mathrm{H}$ stretching vibration & \\
\hline 2920 & $\begin{array}{l}\text { Asymmetric axial deformation of the } \mathrm{C}-\mathrm{H} \text { bond of } \mathrm{CH}_{3} \text { and } \mathrm{CH}_{2} \\
\text { groups }\end{array}$ & \\
\hline 2850 & Symmetric axial deformation of $\mathrm{C}-\mathrm{H}$ bond of $\mathrm{CH}_{3}$ and $\mathrm{CH}_{2}$ groups & \\
\hline 1740 & $\begin{array}{l}\text { Axial deformation of the } \mathrm{C}=\mathrm{O} \text { bond of carboxylic acids, ketones, } \\
\text { aldehydes and esters }\end{array}$ & \\
\hline 1640 & $\begin{array}{l}\text { Axial deformation of } \mathrm{C}=\mathrm{C} \text { bond in aromatic rings, angular } \\
\text { deformation of } \mathrm{N}-\mathrm{H} \text { bond and asymmetric stretching of } \\
\text { carboxylate anion }(\mathrm{COO})\end{array}$ & \\
\hline 1523 & $\begin{array}{l}\text { Angular deformation of } \mathrm{N}-\mathrm{H} \text { bond and asymmetric axial } \\
\text { deformation of carboxylate anion }\left(\mathrm{COO}^{-}\right)\end{array}$ & {$[31,73,74]$} \\
\hline 1442 & $\begin{array}{l}\text { Symmetric axial deformation of carboxylate anion }\left(\mathrm{COO}^{-}\right) \text {and } \\
\text { angular deformation of the } \mathrm{C}-\mathrm{H} \text { bond of } \mathrm{CH}_{3} \text { e } \mathrm{CH}_{2} \text { groups }\end{array}$ & \\
\hline 1371 & Angular deformation of $\mathrm{C}-\mathrm{H}$ bond of $\mathrm{CH}_{3}$ groups & [73] \\
\hline 1241 & Axial deformation of the $\mathrm{C}-\mathrm{O}$ bond of phenols & \\
\hline 1023 & $\begin{array}{l}\text { Asymmetric axial deformation of } \mathrm{O}-\mathrm{C}-\mathrm{C} \text { bonds in pyrans present } \\
\text { in the pectin structure }\end{array}$ & {$[75,76]$} \\
\hline $812-400$ & $\begin{array}{l}\text { Angular deformation out-of-plane of C-H bond of substituted } \\
\text { aromatic rings }\end{array}$ & [72] \\
\hline
\end{tabular}


Table 2. Integrated areas of the main peaks observed in the apple pomace solid-state CPMAS ${ }^{13} \mathrm{C}$ NMR spectrum.

\begin{tabular}{|c|c|c|}
\hline Chemical shift (ppm) & Area $(\%)$ & Assignments \\
\hline $0-45$ & 12.9 & Aliphatic carbons \\
\hline $45-57$ & 4.4 & Methoxyl carbons \\
\hline $57-66$ & 8.6 & \\
\hline $66-82$ & 42.9 & \\
\hline $82-92$ & 6.7 & Alkyl O-carbons \\
\hline $92-100$ & 4.0 & \\
\hline $100-115$ & 8 & \\
\hline $115-161$ & 4.4 & Aromatic carbons \\
\hline $161-200$ & 6.3 & Carbonyl carbons \\
\hline
\end{tabular}

Table 3. Multi-response optimization process

\begin{tabular}{ccc}
\hline Factor & Codified value & Real value \\
\hline$C_{0}$ & -0.167 & $274.95 \mathrm{mg} \mathrm{L}^{-1}$ \\
$m$ & +0.667 & $0.0847 \mathrm{~g}$ \\
$p H$ & +1 & 10.0 \\
\hline
\end{tabular}


Table 4. Isotherm parameters for MB adsorption onto apple pomace

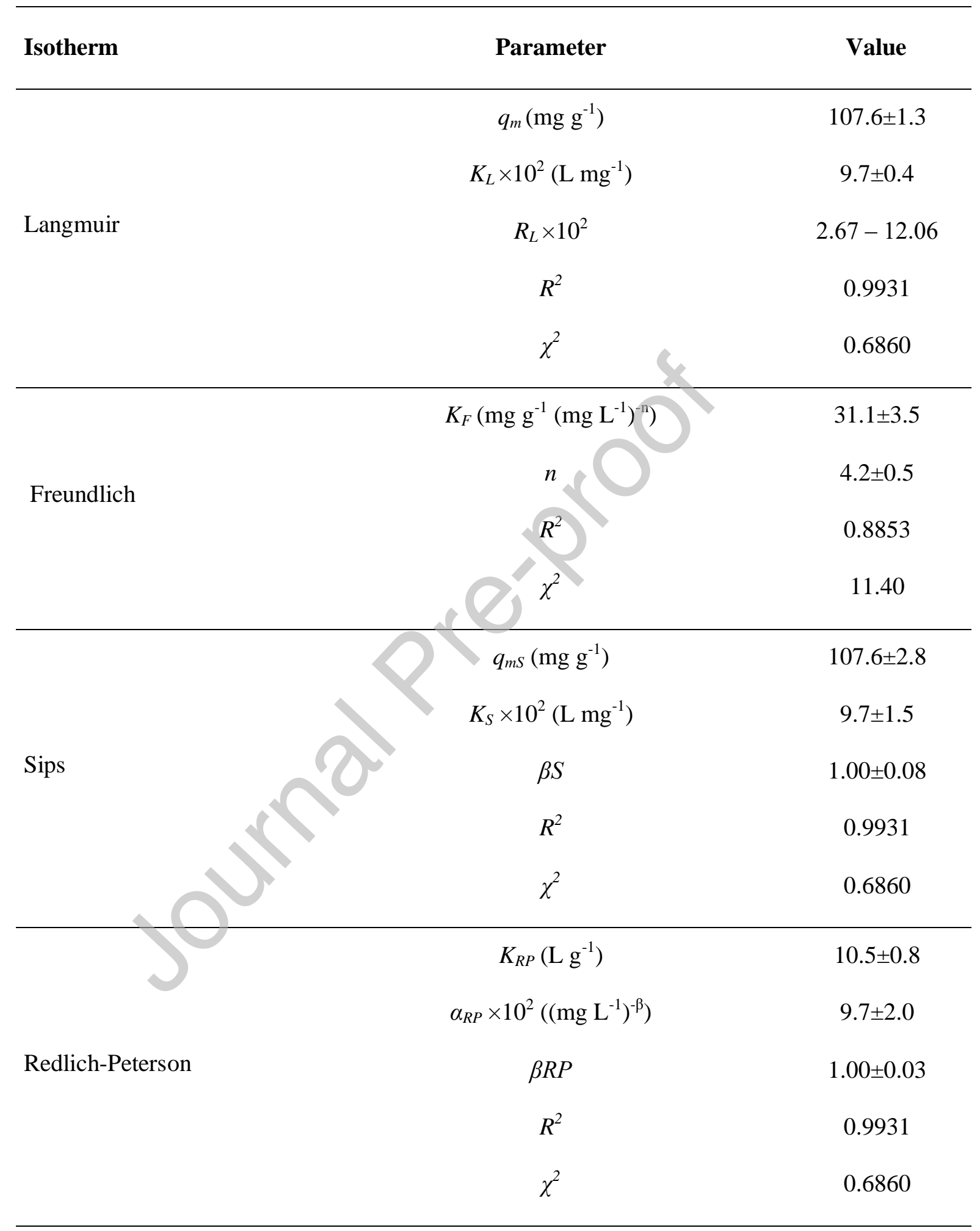


Table 5. Comparison of sorption capacities of various adsorbents for MB

\begin{tabular}{lcc}
\hline Adsorbent & $\boldsymbol{q}_{\boldsymbol{m}}\left(\mathbf{m g ~}^{\mathbf{- 1}}\right)$ & Reference \\
\hline $\begin{array}{l}\text { KOH-activated carbon prepared from sucrose spherical } \\
\text { carbon }\end{array}$ & 704.2 & {$[77]$} \\
$\mathrm{TiO}_{2} @$ C nanosheets & 441.0 & {$[78]$} \\
Dehydrated peanut hull & 108.6 & {$[79]$} \\
Apple pomace & 107.6 & This study \\
Parthenium hysterophorus phosphoric acid activated & 88.5 & {$[80]$} \\
Fe-Mn binary oxide nanoparticles & 72.3 & {$[81]$} \\
Pyrophyllite & 70.4 & {$[82]$} \\
Raw KT3B kaolin (Algeria) & 52.8 & {$[83]$} \\
Yellow passion fruit waste & 44.7 & {$[84]$} \\
Olive pomace & 42.3 & {$[85]$} \\
Eggshell & 0.8 & {$[86]$} \\
\hline
\end{tabular}

Table 6. Thermodynamics parameters for the adsorption of MB onto apple pomace

\section{Thermodynamics}

Temperature

(K)

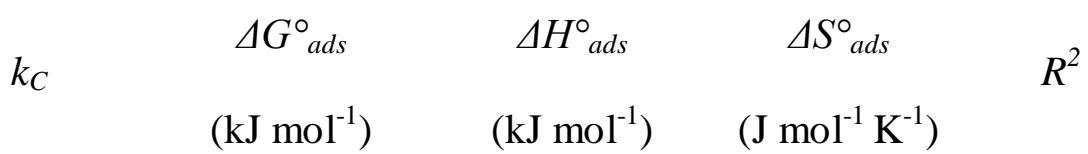

$278 \quad 2.97 \pm 0.04 \quad-2.52 \pm 0.03$

$288 \quad 2.02 \pm 0.02 \quad-1.67 \pm 0.08$

$-9.8 \pm 1.9 \quad-62.7 \pm 6.6 \quad 0.9813$

$298 \quad 1.54 \pm 0.02 \quad-1.04 \pm 0.09$

$\begin{array}{lll}308 & 2.97 \pm 0.04 & -0.59 \pm 0.07\end{array}$ 
Table 7. Kinetic parameters for MB removal onto apple pomace.

\begin{tabular}{|c|c|c|c|}
\hline & \multicolumn{3}{|c|}{ Initial concentration of $\mathrm{MB}$ dye $\left(\mathrm{mg} \mathrm{L}^{-1}\right)$} \\
\hline & 100 & 200 & 300 \\
\hline \multicolumn{4}{|l|}{ Pseudo-first-order } \\
\hline$q_{e}\left(\mathrm{mg} \mathrm{g}^{-1}\right)$ & $52.4 \pm 0.8$ & $88.2 \pm 1.4$ & $98.0 \pm 1.3$ \\
\hline$k_{1} \times 10\left(\min ^{-1}\right)$ & $2.3 \pm 0.2$ & $2.5 \pm 0.3$ & $2.1 \pm 0.2$ \\
\hline $\mathrm{R}^{2}$ & 0.9803 & 0.9800 & 0.9872 \\
\hline$\chi^{2}$ & 1.554 & 936 & 1.402 \\
\hline \multicolumn{4}{|l|}{ Pseudo-second-order } \\
\hline$q_{e}\left(\mathrm{mg} \mathrm{g}^{-1}\right)$ & $54.2 \pm 0$ & $90.8 \pm 0.8$ & $101.4 \pm 0.5$ \\
\hline$k_{2} \times 10^{3}\left(\mathrm{~g} \mathrm{mg}^{-1} \mathrm{~min}^{-1}\right)$ & $8.5 \pm 0.7$ & $6.0 \pm 0.6$ & $4.2 \pm 0.2$ \\
\hline $\mathrm{R}^{2}$ & 0.9965 & 0.9954 & 0.9984 \\
\hline$\chi^{2}$ & 0.204 & 0.442 & 0.162 \\
\hline \multicolumn{4}{|l|}{ Elovich } \\
\hline$\alpha_{E}\left(\mathrm{mg} \mathrm{g}^{-1} \min ^{-1}\right)$ & $118.4 \pm 25.3$ & $134.3 \pm 34.7$ & $123.8 \pm 26.9$ \\
\hline$\beta_{E} \times 10\left(\mathrm{~g} \mathrm{mg}^{-1}\right)$ & $2.9 \pm 0.5$ & $1.9 \pm 0.3$ & $1.5 \pm 0.3$ \\
\hline $\mathrm{R}^{2}$ & 0.9819 & 0.9843 & 0.9779 \\
\hline$\chi^{2}$ & 0.946 & 1.352 & 2.250 \\
\hline \multicolumn{4}{|l|}{ Intra-particle diffusion } \\
\hline$k_{\text {int }}\left(\mathrm{mg} \mathrm{g}^{-1} \min ^{-1 / 2}\right)^{\mathrm{a}}$ & $4.4 \pm 0.5$ & $6.8 \pm 1.5$ & $9.8 \pm 0.4$ \\
\hline $\mathrm{R}^{2}$ & 0.9884 & 0.9549 & 0.9981 \\
\hline$\chi^{2}$ & 0.013 & 0.072 & 0.005 \\
\hline
\end{tabular}

${ }^{\mathrm{a}}$ First stage 


\section{Declaration of interests}

$\bigotimes$ The authors declare that they have no known competing financial interests or personal relationships that could have appeared to influence the work reported in this paper.

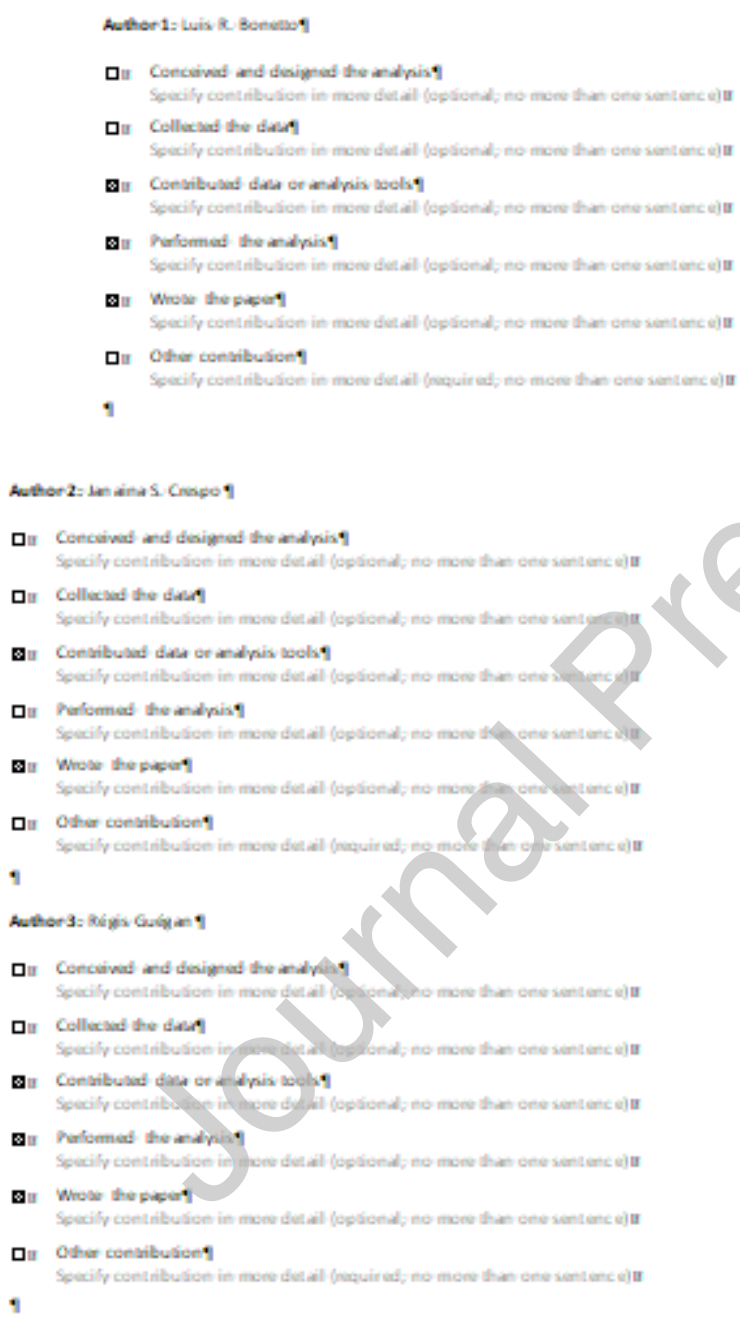




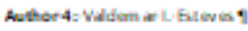

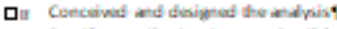

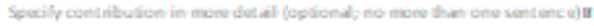

QII Collocian the dise

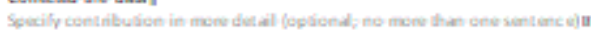

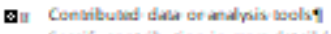

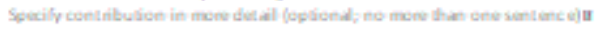

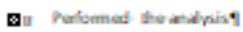

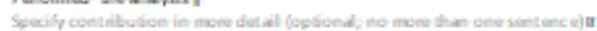

QII Whow the packer?

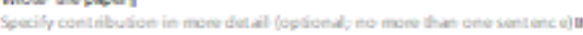

QII Odter westitution?

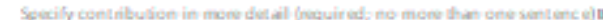

Authors: Marc do Gionedas

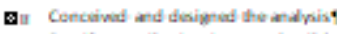

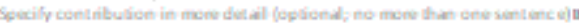

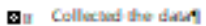

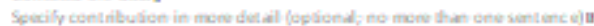

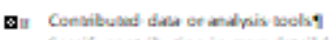

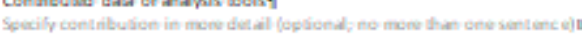

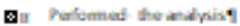

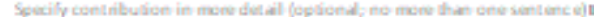

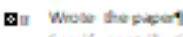

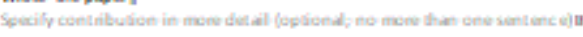

QII OAtur consituation?

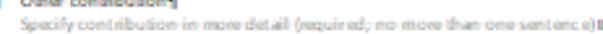




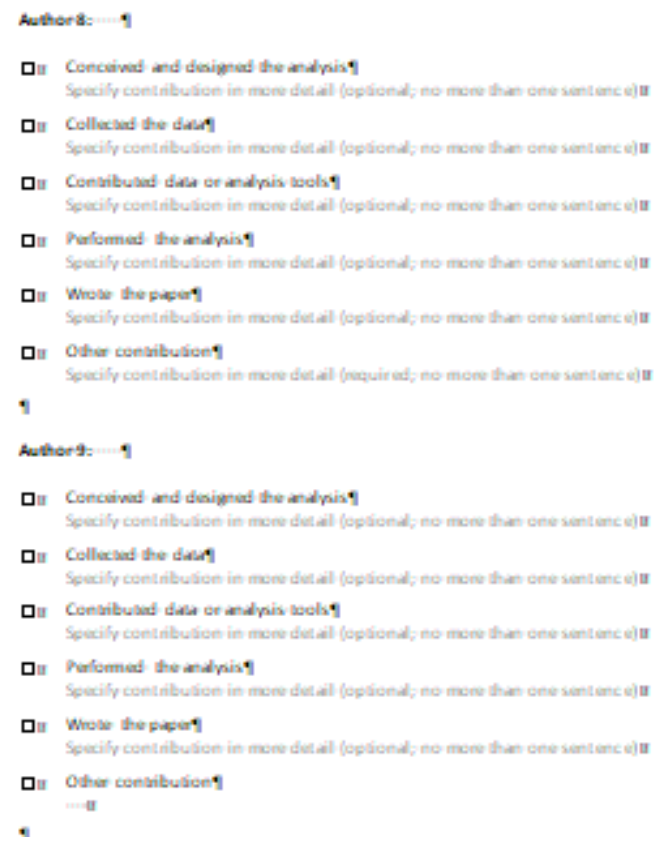

Wuther 10: fiter wi thor nume 9

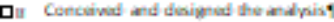

II Collociad the dine

Coesibuad data or molpix bols?

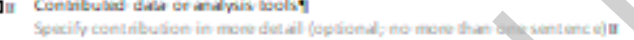

QII Purtomed the minis?

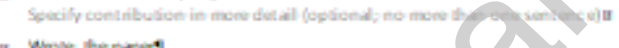

aII Whose the pasen

DII Odher coesitudion

I

\section{Graphical}

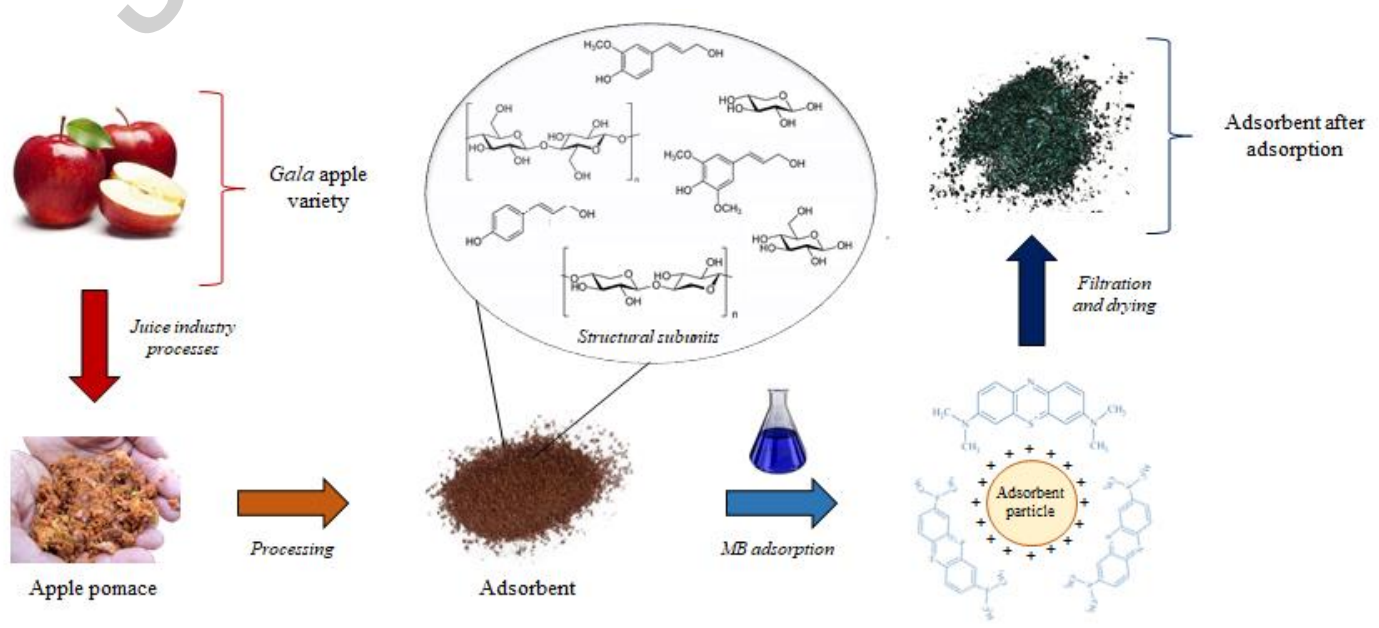

